Prepared for the U.S. Department of Energy under Contract DE-AC05-76RL01830

\title{
FY 2009 Progress: Process Monitoring Technology Demonstration at PNNL
}

\author{
LM Arrigo \\ RN Christensen \\ CG Fraga \\ M Liezers \\ SM Peper \\ EM Thomas
}

AJ Casella

DC Duckworth

TG Levitskaia

CR Orton

JM Schwantes

RM Ward

December 2009

Pacific Northwest

NATIONAL LABORATORY

Proudly Operated by Battelle Since 1965 


\title{
DISCLAIMER
}

This report was prepared as an account of work sponsored by an agency of the United States Government. Neither the United States Government nor any agency thereof, nor Battelle Memorial Institute, nor any of their employees, makes any warranty, express or implied, or assumes any legal liability or responsibility for the accuracy, completeness, or usefulness of any information, apparatus, product, or process disclosed, or represents that its use would not infringe privately owned rights. Reference herein to any specific commercial product, process, or service by trade name, trademark, manufacturer, or otherwise does not necessarily constitute or imply its endorsement, recommendation, or favoring by the United States Government or any agency thereof, or Battelle Memorial Institute. The views and opinions of authors expressed herein do not necessarily state or reflect those of the United States Government or any agency thereof.

\author{
PACIFIC NORTHWEST NATIONAL LABORATORY \\ operated by \\ BATTELLE \\ for the \\ UNITED STATES DEPARTMENT OF ENERGY \\ under Contract DE-AC05-76RL01830
}

Printed in the United States of America
Available to DOE and DOE contractors from the Office of Scientific and Technical Information,
P.O. Box 62, Oak Ridge, TN 37831-0062;
ph: (865) 576-8401
fax: $(865)$ 576-5728
email: reports@adonis.osti.gov

\begin{abstract}
Available to the public from the National Technical Information Service, U.S. Department of Commerce, 5285 Port Royal Rd., Springfield, VA 22161 ph: (800) 553-6847 fax: $(703) 605-6900$ email: orders@ntis.fedworld.gov online ordering: http://www.ntis.gov/ordering.htm
\end{abstract}

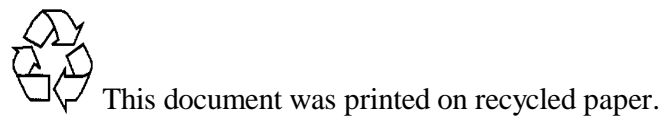




\section{FY 2009 Progress: Process Monitoring Technology Demonstration at PNNL}

$\begin{array}{lll}\text { LM Arrigo } & \text { SA Bryan } & \text { AJ Casella } \\ \text { RN Christensen } & \text { M Douglas } & \text { DC Duckworth } \\ \text { CG Fraga } & \text { AR Laspe } & \text { TG Levitskaia } \\ \text { M Liezers } & \text { AM Lines } & \text { CR Orton } \\ \text { SM Peper } & \text { JM Peterson } & \text { JM Schwantes } \\ \text { EM Thomas } & \text { RM Ward } & \end{array}$

December 2009

Prepared for

the U.S. Department of Energy

under Contract DE-AC05-76RL01830

Pacific Northwest National Laboratory

Richland, Washington 99352 



\section{Executive Summary}

The International Atomic Energy Agency has established international safeguards standards for fissionable material at spent fuel reprocessing plants to ensure that significant quantities of weaponsgrade nuclear material are not diverted over a specified time frame. Currently, methods to verify that the facilities are operating under adequate safeguard-declared conditions require time consuming sampling and expensive, destructive analysis. The time delay between sampling and subsequent analysis provides a potential opportunity to divert the material out of the appropriate chemical stream. One way to avoid this problem is to use process monitoring equipment that is capable of on-line and in near-real-time monitoring of the flow sheet radiochemical streams to rapidly identify deviations from normal operating conditions. Three integrated systems for flow sheet monitoring are currently being developed at Pacific Northwest National Laboratory (PNNL) including 1) a multi-isotope process monitor (MIP), 2) a spectroscopy-based monitor utilizing UV-Vis-NIR (ultraviolet-visible-near infrared) and Raman spectrometers, and 3) an electrochemically modulated separations approach (EMS). MIP uses gamma spectroscopy and pattern recognition software to identify off-normal conditions in process streams. The UV-Vis-NIR and Raman spectroscopic monitoring continuously measures chemical compositions of the process streams including actinide metal ions (uranium, plutonium, and neptunium), selected fission products, and major cold flow sheet chemicals. EMS provides an on-line means for pre-separating and pre-concentrating elements of interest out of complex matrices prior to detection via non-destructive assay by gamma spectroscopy or destructive analysis with mass spectrometry.

Last FY, PNNL reported some of its initial modeling work as proof of principle. In this FY 2009 progress report, we provide a general overview of the performance of these technologies in the demonstrations that were carried out using spent nuclear fuel. The MIP monitor technology work scope had three specific goals, 1) to evaluate the sensitivity of the technology using spent nuclear fuel dissolver solutions that had undergone the first separation phase of a PUREX-type separation, 2) to optimize the multivariate analysis algorithm used based on the results of the test with the separated SNF solution, and 3) to demonstrate the applicability of the MIP monitor for predicting SNF burnup. The sensitivity of the MIP monitor was evaluated by using the gamma spectrum from the organic extract phase to indirectly determine the acid concentration of the acid feed phase. It was determined that the MIP monitor was able to accurately measure the acid concentration to within $0.1 \mathrm{M}$ at three sigma (three standard deviations from the mean, which corresponds to the 99.9 percent confidence interval). This result, albeit quite promising was found to be subject to two experimental biases; a small sample size $(\mathrm{N}=9)$ and a slightly nonlinear biphasic extraction model upon which the prediction algorithm was based. Using simulated gamma spectra, the acid concentration of the acid feed was predicted, as done for the separated SNF solution, for a $16 \mathrm{MWd} / \mathrm{kgU}$ boiling water reactor fuel that had been cooled for 26 years. The sensitivity was determined to be within $0.05 \mathrm{M}$ at three sigma. This prediction has yet to be experimentally verified, but suggests a tremendous sensitivity of this technology for monitoring minute variations in process conditions, which are of paramount importance if one were trying to detect special nuclear material diversion via a trickle diversion methodology. The evaluation of the MIP monitor for predicting spent fuel burnup was also quite successful, being able to accurately determine burnup for a simulated fuel to within 0.1 percent using simulated spectra. This capability is rather promising for safeguards inspections at reprocessing facilities since it could be used to help minimize shipper-receiver differences and thereby significantly decrease the material unaccounted for by providing a valuable piece of complimentary data to the nuclear material accountancy measurements performed by the IAEA on the input accountancy tanks. 
Spectroscopy-Based Monitoring has two inherent advantages due to its suitability for performing qualitative and quantitative measurements; both the potential applicability for process monitoring and nuclear material accountancy measurements. This is why, in part, the scope of work for the evaluation of the Spectroscopy-Based Monitoring system focused on both the sensitivity (detection limit) and the uncertainty (relative standard deviation) determination of this technology. Simulated process feed solutions containing uranium, neptunium or plutonium were used for the performance analyses. The Raman technology, which is used to determine the uranium concentration, yielded a detection limit of 3.1 $\mathrm{mM}$ and a relative standard deviation of 0.8 percent. This result is quite promising as it compares rather well to the performance of the safeguards benchmark technology, hybrid K-edge densitometry, which has a relative standard deviation around 0.7 percent. For plutonium and neptunium measurements a visiblenear infrared spectrometer coupled to fiber optic probes were used. This method provided a detection limit for tetravalent plutonium of $80 \mu \mathrm{M}$ with a relative standard deviation of 1.7 percent, while neptunium measurements yielded a detection limit of $0.1 \mathrm{mM}$ for pentavalent neptunium with a relative standard deviation of 5.6 percent and a relative standard deviation for hexavalent neptunium of 1.1 percent, respectively. The ability to rapidly measure neptunium quantitatively is quite significant due to the use of neptunium concentrations by the IAEA for performing flowsheet verification.

The electrochemically-modulated separation technology was evaluated as a means of separating and pre-concentrating plutonium from spent nuclear fuel dissolver solutions so that it could be quantified by gamma spectrometry. This experimental test was designed to attempt to validate the gamma spectra modeled last year for a spent fuel sample of comparable pedigree and burnup. Although this technology was able to demonstrate pre-concentration of plutonium using mass spectrometric detection, gamma spectroscopy was unable to observe a significant change in the gamma spectra before and after the separation was applied. The complex matrix of dissolver solution presented some unforeseen challenges, such as co-deposition of tetravalent zirconium. The NA-22 Safeguards Portfolio has recently committed to funding additional research and development that is needed to improve the performance of this technology for safeguards applications. 


\section{Acronyms and Abbreviations}

AMUSE

ANL

BWR

EMS

HPGe

IUPAC

MIP

PCA

PLS

PNNL

PUREX

RMSEP

SASPE

TBP

VIS-NIR

UREX+

UV-Vis-NIR
Argonne National Laboratory's Model for Universal Solvent Extraction Argonne National Laboratory

boiling water reactor

electrochemically modulated separations

high-purity germanium

International Union of Pure and Applied Chemistry

multi-isotope process monitor

principal component analysis

partial least squares

Pacific Northwest National Laboratory

plutonium-uranium extraction

root mean squared error of the prediction

Spreadsheet Algorithm for Speciation and Partitioning Equilibria

tri-butyl phosphate

visible-near-infrared

uranium reduction and extraction

ultraviolet-visible-near infrared 



\section{Contents}

Executive Summary ...................................................................................................... iii

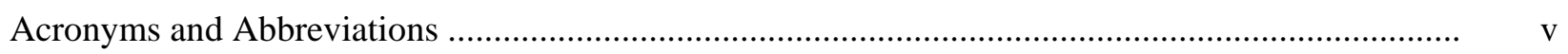

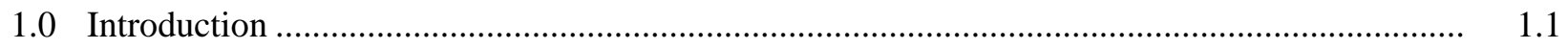

2.0 FY 2009 Progress: Multi-Isotope Process Monitor .......................................................... 2.1

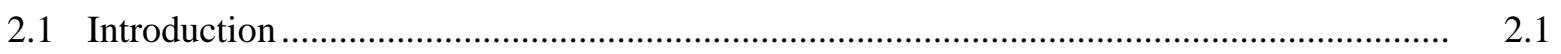

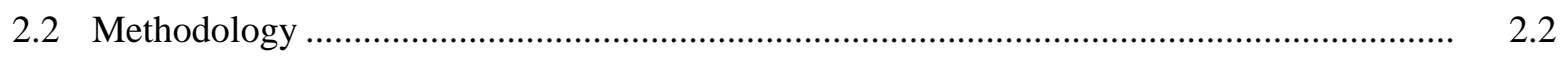

2.2.1 Methodology of the Simulations ................................................................. 2.2

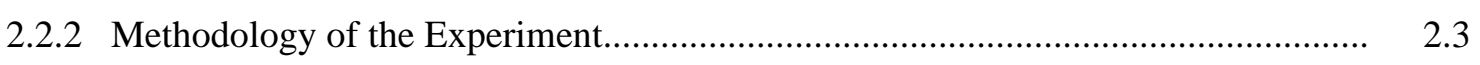

2.2.3 Multivariate Analysis Techniques................................................................ 2.4

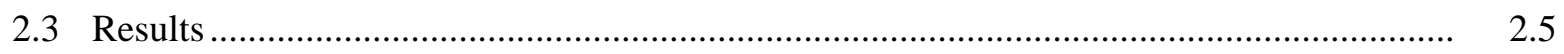

2.3.1 Non-Optimized Experimental Estimation of MIP Monitor for Determining Acid Concentration ..................................................................................... 2.5

2.3.2 Simulated Sensitivity of the MIP Monitor for Monitoring Acid Concentration ....... 2.7

2.3.3 Simulated Sensitivity of the MIP Monitor for Determination of Burnup ................ 2.8

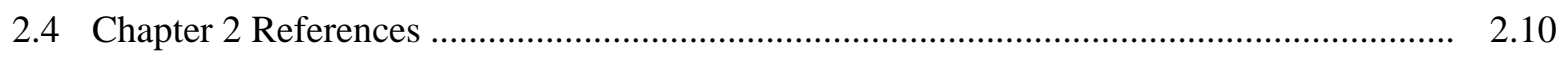

3.0 FY 2009 Progress: Spectroscopy-Based Monitoring ...................................................... 3.1

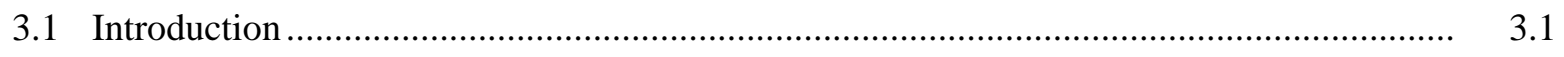

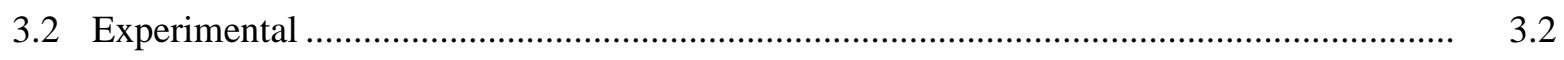

3.3 Process Monitoring Instrumentation ...................................................................... 3.2

3.3.1 Uranium (VI) Analysis ............................................................................ 3.2

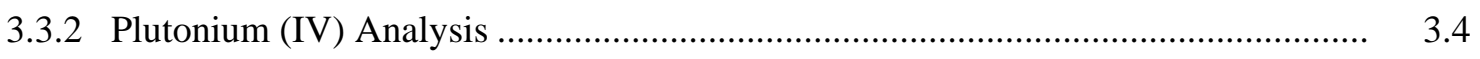

3.3.3 Neptunium(V, VI) Analysis .................................................................... 3.6

3.4 Chapter 3 References ......................................................................................... 3.9

4.0 FY 2009 Progress: Electrochemically Modulated Separations .............................................. 4.1

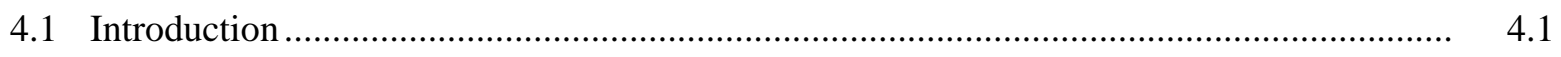

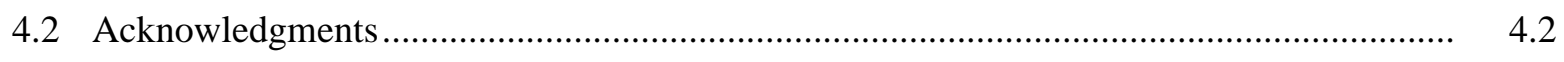

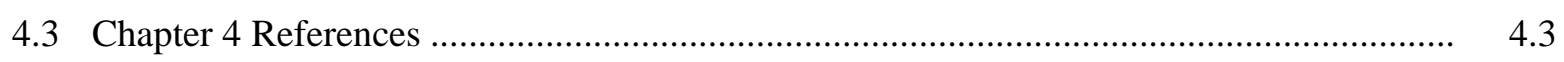




\section{Figures}

2.1 Simulated Gamma Spectra Generated from an HPGe Detector for BWR fuel, 69 to 70 $\mathrm{MWd} / \mathrm{kgU}$ And 16-Years Cooled, as a Function of Acid Concentration ................................... 2.5

2.2 PCA Grouping of the Spectra Shown in Figure 2.1 ............................................................ 2.6

2.3 PLS Model Results Generated from Data Shown in Figure 2.2 …........................................ 2.6

2.4 Simulated Gamma Spectra Generated from HPGe Detector as a Function of Acid Concentration for Spent BWR Fuel (16 MWd/kgU, 26-year cooling) ....................................... 2.7

2.5 PLS Model Results from the Spectra Shown in Figure 2.4 .................................................. 2.8

2.6 Simulated Gamma Spectra of Three-Year Cooled Dissolved Spent Fuel as a Function of Burnup

2.7 PLS Model Results Generated from the Spectra Shown in Figure 2.6 After Mean Centering and Normalization

2.8 PLS Model Results Generated from the Spectra Shown in Figure 2.6 After Mean Centering..... 2.10

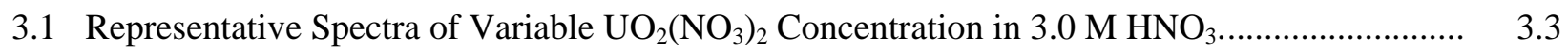

3.2 Raman Response $\left(870 \mathrm{~cm}^{-1}\right)$ versus $\mathrm{UO}_{2}{ }^{2+}$ Solution Concentration ........................................ 3.3

3.3 Sample Spectra of $\mathrm{UO}_{2}\left(\mathrm{NO}_{3}\right)_{2}$ in Nitric Acid Measured as a Function of Time ....................... 3.4

3.4 Baseline-corrected VIS-NIR spectra for Pu (IV) in $1.33 \mathrm{M} \mathrm{UO}_{2}\left(\mathrm{NO}_{3}\right)_{2}$ and $0.8 \mathrm{M} \mathrm{HNO}_{3} \ldots \ldots \ldots . \quad 3.5$

3.5 Calibration Plots for the Baseline-Corrected Plutonium (IV) Absorbance Spectra Shown in

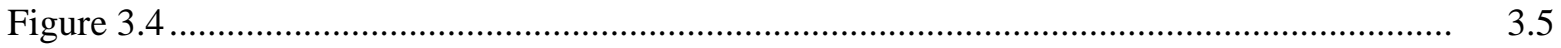

3.6 Sample Spectra for a Solution of Approximately $0.9 \mathrm{mM} \mathrm{Pu}\left(\mathrm{NO}_{3}\right)_{4}$ in a Matrix of $1.33 \mathrm{M}$

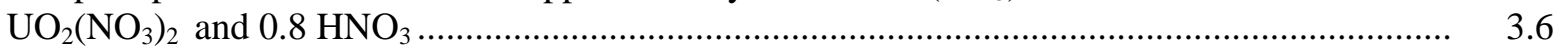

3.7 (left) Spectra of Neptunium (V) Added to Fuel Feed Simulant (right) Linear Calibration Curve of Neptunium (V) VIS-NIR Data in Simple Feed Solution.....

3.8 Variable Concentration Neptunium (V and VI) Standard Spectra Used as the Training Set for Chemometric Analysis

3.9 Linear Calibration Plots for Neptunium (V, VI) Data ........................................................ 3.8

3.10 Long-Term Neptunium (V, VI) Spectral Measurements ....................................................... 3.9

4.1 (left) Experimental Setup; (right) Small Volume Flow-by Electrochemical Cell for EMS, Showing the Three Electrode Cell.

\section{Tables}

4.1 Results from the First Test of EMS Separation of Plutonium From BWR Fuel 


\subsection{Introduction}

Pacific Northwest National Laboratory (PNNL) is developing and demonstrating three technologies designed to assist in the monitoring of reprocessing facilities in near-real time. These technologies include 1) a multi-isotope process monitor (MIP), 2) a spectroscopy-based monitor that uses UV-Vis-NIR (ultraviolet-visible-near infrared) and Raman spectrometers, and 3) an electrochemically modulated separations approach (EMS). The MIP monitor uses gamma spectroscopy and pattern recognition software to identify off-normal conditions in process streams. The UV-Vis-NIR and Raman spectroscopic monitoring continuously measures chemical compositions of the process streams including actinide metal ions (uranium, plutonium, neptunium), selected fission products, and major cold flow sheet chemicals. The EMS approach provides an on-line means for separating and concentrating elements of interest out of complex matrices prior to detection via nondestructive assay by gamma spectroscopy or destructive analysis with mass spectrometry. A general overview of the technologies and ongoing demonstration results are described in this report.

PNNL has hot cell facilities where two segments of spent nuclear fuel were dissolved for use in the demonstrations of all three process monitoring technologies discussed here: 1) a segment of low burnup (i.e., $16 \mathrm{MWd} / \mathrm{kgU}$ ) boiling water reactor (BWR) fuel with a decay time of 26 years, and a segment of high burnup (i.e., $\sim 67 \mathrm{MWd} / \mathrm{kgU}$ ) BWR fuel with a decay time of 16 years. Both fuels have been characterized previously (Vaidyanathan 1997, Guenther 1998, Wolf 2005). These fuels were dissolved in nitric acid and a portion of each fuel solution was brought up in the following acid concentrations: 0.1 , 1.3, 2.5, 3.8, and 5.1 $\mathrm{M}$ nitric acid. Both sets of spent fuel solutions, high burnup and low burnup, were used in the MIP and UV-Vis-NIR demonstration, while only the high burn up solution was used in the EMS demonstration. 



\title{
2.0 FY 2009 Progress: Multi-Isotope Process Monitor
}

\author{
Jon Schwantes, ${ }^{1}$ Carlos Fraga, ${ }^{1}$ Christopher Orton, ${ }^{1,2}$ \\ Richard Christensen, ${ }^{2}$ Amy Laspe, ${ }^{3}$ Rebecca Ward ${ }^{4}$
}

\subsection{Introduction}

Modern industrial reprocessing techniques, including the plutonium-uranium extraction (PUREX) and uranium reduction and extraction (UREX+) family of separations technologies, are based on solvent extraction between organic and aqueous phases. In these bi-phase systems, product (actinide) and contaminant (fission and activation products) elements are preferentially driven (thermodynamically) to opposite phases, with small amounts of each remaining in the other phase (Benedict, Pigford, and Levi 1981).

The distribution of each element between the organic and aqueous phases is determined by major process variables such as acid concentration, organic ligand concentration, reduction potential, and temperature. Hence, for consistent performance of the separation process, the distribution of each element between the organic and aqueous phases should be relatively constant. During "normal" operations, the pattern of elements distributing into the product and waste streams at each segment of the facility should be reproducible, thereby resulting in a statistically significant signature of the nominal process conditions. Under "abnormal" conditions, such as those expected under some protracted diversion scenarios, patterns of elements within the various streams would be expected to change measurably.

The multi-isotope process (MIP) monitoring approach uses changes in the concentrations of gammaemitting elements as evidence of changes to the process chemistry (Smith et al. 2007, Schwantes et al. 2008, Orton et al. 2008). It exploits a suite of gamma-emitting isotopes to track multiple chemical species and behaviors simultaneously, thus encompassing a large array of elements that are affected by chemical and physical changes. In-process surveillance by the MIP monitor is accomplished by coupling the gamma spectrometry of the streams with multivariate techniques, such as principal component analysis (PCA). PCA is a chemometrics tool that finds combinations of variables (principal components) that best describe the common variance between differing datasets (Malinowski 2008). Using multivariate analysis, such as PCA, the MIP monitoring technique is then capable of automatically evaluating the patterns of the gamma-emitting contaminants for statistically relevant signs of potential changes to the process chemistry. The MIP monitor represents the first of its technology to combine gamma-ray spectroscopy with multivariate analysis for monitoring reprocessing operations.

\footnotetext{
1 Advanced Radioanalytical Chemistry Group, National Security Directorate, Pacific Northwest National Laboratory, Richland, Washington.

2 Professor, Nuclear Engineering Department, The Ohio State University, Columbus, Ohio

3 NSIP Student Intern, University of Wisconsin, Madison, Wisconsin.

${ }^{4}$ NSIP Student Intern, University of Texas, Austin, Texas.
} 


\subsection{Methodology}

\subsubsection{Methodology of the Simulations}

A group of three computer models was used in series to simulate gamma spectra from reprocessing streams to test the MIP monitor concept. Spent boiling water reactor (BWR) fuel was modeled using the ORIGEN-ARP code (Croff 1983). The fuel was modeled with various burnup levels for comparison purposes. The fuel type selected in ORIGEN-ARP (which includes the cross section libraries) was General Electric BWR fuel with 3-percent enrichment.

As output, ORIGEN-ARP provides quantity, weight, and activity of the elements and isotopes in the fuel. This output was used as a basis for predicting the elemental and isotopic composition in a simulated dissolved fuel solution. The results from the ORIGEN-ARP simulation were used as input for Argonne National Laboratory's (ANL) Model for Universal Solvent Extraction (AMUSE) (Regalbuto et al. 2009, Vandegrift 1993, Leonard and Regalbuto 1994) code to simulate solvent extraction. In its entirety, AMUSE can calculate the steady-state compositions for both the aqueous and organic phases at each contactor stage for various processes and also estimate the size and cost of the necessary equipment. For the purposes of this study, only a portion of the code (Spreadsheet Algorithm for Speciation and Partitioning Equilibria [SASPE]) was used to calculate the batch extraction distribution coefficient for the primary uranium and plutonium extraction in a PUREX process. Regalbuto et al. (2009) explain that SASPE uses input compositions and the conditions of the aqueous and organic phases to calculate the distribution ratios. These calculations employ chemically-correct models that use the thermodynamic activities of the major aqueous species. The approach of Bromley (1973) is used to calculate these activities from aqueous-phase compositions. Solvent loading also is incorporated into the distribution coefficient.

An aqueous feed solution with a standard uranium concentration of $1.3 \mathrm{M}$ for a typical PUREX process was modeled (Benedict, Pigford, and Levi 1981). Concentrations of major radioactive fission products were included in accordance to their respective ratios to the uranium in the dissolved fuel as simulated by ORIGEN-ARP. All fission and activation products were assumed to have dissolved completely into solution. The total element concentration of the selected nuclides were entered into AMUSE, and the distribution coefficient was calculated based on simulated contact with a 30-percent (V/V) tri-butyl phosphate (TBP) in dodecane in a two-to-one volume ratio with the aqueous phase. The distribution coefficients were calculated at different nitric acid concentrations of the feed solution.

The output from AMUSE consisted of the distribution coefficients for each element. Elements included in AMUSE defined by the default distribution coefficient included barium, carbon, cadmium, and cesium. In addition, the palladium distribution coefficients as a function of acid concentration from literature (Ishimori and Watanabe 1960) were used instead of the default constant. The input to AMUSE assumed that all of the plutonium existed in the tetravalent oxidation state. This assumption was adequate because the gamma rays from plutonium did not add appreciably to the overall spectra of spent fuel. AMUSE did not have the capability to model distribution coefficients for antimony, tellurium, tin, nickel, and niobium. These elements were left out of the model simulations.

The distribution coefficients generated by AMUSE were used to derive the element concentrations in both the organic extract and aqueous raffinate solutions. The fraction of each element extracted combined 
with its relative isotopic abundances from ORIGEN-ARP output were used to distribute the nuclide activity between phases and propagate a list of nuclides and their activity. The nuclide activity list was used as source characterization for input into a third computer program, PNNL's Synth code (Hensley et al. 1995), to simulate gamma spectra of the feed, raffinate and organic extract solutions. Synth is a onedimensional radiation transport code designed to mimic the response of a selected detector type among several choices, including sodium iodide, high-purity germanium (HPGe) and cadmium zinc telluride crystals. Spectra are populated based on the nuclide source list and a library that attributes the gamma rays and their branching ratios to each nuclide. Here, the gamma spectrum from the dissolver and the organic extract were simulated using HPGe.

For all spectral simulations, a point source was assumed. For the acid concentration variations, the energy calibration was set to $0.5 \mathrm{keV}$ per channel, and 4096 channels were used, resulting in a full-scale energy of $2048 \mathrm{keV}$. The live time was set to one hour and the source was located $5 \mathrm{~cm}$ from the detector. For the direct measurement of dissolver solutions, the detector was modeled with $0.3 \mathrm{keV}$ per channel with 8192 channels, resulting in an energy scale up to $2457 \mathrm{keV}$. The count time was 10 minutes and the source was located $10 \mathrm{~cm}$ from the detector. The HPGe detector was a coaxial model with 50-percent efficiency and the default settings were used, including a resolution of $1.9 \mathrm{keV}(0.14 \%)$ at $1332 \mathrm{keV}$ (Hensley et al. 1995). These gamma spectra for the organic extract and aqueous dissolver were simulated as a function of acid concentration and burnup level, respectively.

\subsubsection{Methodology of the Experiment}

A segment of BWR spent commercial nuclear fuel was used in the experimental analysis of the MIP monitor. The dissolution and separation of the fuel was performed at the Shielded Analytical Laboratory hot cell facility at PNNL. The segment of fuel used in the experiment was part of the ATM 109 fuel rod group, which was BWR fuel irradiated in the Quad Cities I reactor. This rod was fabricated by General Electric, post-irradiation examinations were performed at General Electric's Vallecitos Nuclear Center, and the fuel was sent to ANL and then to PNNL for use as an Approved Testing Material. The segment of fuel dissolved for the demonstration had an initial enrichment of 3 percent and a burnup of approximately 67 to $70 \mathrm{MWd} / \mathrm{kgU}$. The fuel was irradiated from February 1979 until September 1987 at which time the rod was removed from its bundle and placed in a carrier assembly. The carrier assembly was reinserted into the reactor and irradiated from November 1989 until September 1992 (Vaidyanathan et al. 1997; Wolfe, Bowers, and Cunnane 2005). As of September 2009, the fuel had been cooling for approximately 17 years.

The dissolution and extraction of the fuel segment was performed in a hot cell by manipulators. The segment was removed from its cladding (12 to $15 \mathrm{~g}$ ) and dissolved in concentrated nitric acid. The undissolved fines were removed by centrifuging the solution. A total of five feed/dissolver samples were prepared for solvent extraction by a TBP-dodecane mixture. Each of these feed solutions had a uranium concentration of roughly $0.7 \mathrm{M}$ and nitric acid concentrations of approximately $0.3,1.3,2.5,3.8$, and 5.1 $\mathrm{M}$, respectively. Following dissolution, each of the fuel segments underwent the first stage of a PUREXtype extraction in batch fashion. These aqueous samples were mixed with an equal volume of 30-percent (V/V) TBP in dodecane solution and then centrifuged to separate the phases. Portions of the feed, aqueous raffinate, and organic extract were removed and stored for analysis. 
The samples were removed from the hot cell for additional preparation and analysis. The solutions were sub-sampled to reduce the gross amount of radiation emitted by each sample. Portions $(0.1 \mathrm{~mL}) \mathrm{of}$ each sample were placed in 4-mL glass vials and diluted to $1 \mathrm{~mL}$ with $0.5 \mathrm{M}$ nitric acid (aqueous samples) or 30-percent (V/V) TBP in dodecane (organic samples) to provide sufficient volume to facilitate collimation during counting. In the case of the organic samples, the radiation levels of the undiluted samples were already low, but the sub-sampling during dilution further eliminated any aqueous carryover incompletely separated in the hot cell.

Gamma counting was performed in PNNL's Radiological Process Laboratory using an HPGe detector. The organic samples were counted on either a 70- or a 74-percent relative efficiency germanium detector at close range for a total live count time of 2 hours. Calibrations, performed on the detector daily, showed minimal drift (approximately $\pm 0.1 \mathrm{keV}$ ). All samples were counted at least once. The five organic extract samples were also counted 10 times each in a random order, resulting in additional spectra for use with PCA.

\subsubsection{Multivariate Analysis Techniques}

Several multivariate analyses were performed on the data set for each detector, including hierarchical cluster analysis, PCA, and the partial least squares (PLS) method. The PLS Toolbox (PLS Toolbox 2008) for Matlab (Matlab 2009) was used to perform all of the multivariate analyses mentioned above. All of the techniques required data preprocessing before they could be applied. In our case, preprocessing consisted of normalization to a unit area and mean-centering. Normalizing by area removes the effect of source intensity on the spectra while maintaining the pattern. Although intensity is a valid indicator of fuel history or process conditions, it also is easily influenced by source/detector geometry. While this effect can be easily managed during simulations, it may be difficult to control size and geometry of the samples to maintain precision between samples during an actual deployment. Normalization should reduce these artificial pattern variances. Because normalization would be used in an actual deployment, it was used exclusively for the first step of the simulated data preprocessing.

The analysis of the spectra included both supervised and unsupervised pattern recognition. To establish groups of interest and compare new samples to the groups, supervised pattern recognition takes into account sample information, such as which samples are normal and which are off-normal. Unsupervised pattern recognition does not consider the sample's origins; instead, it allows the samples to group based solely on the similarities and differences found in the spectra. This approach allows the intrinsic organization to emerge, thus resulting in increased insight into the reaction of the samples to the analysis technique.

After analysis by PCA, the PLS method was applied to the organic extract spectra to predict the acid concentration of the fuel represented by the spectra. PLS is a multivariate calibration method that uses an approach analogous to PCA. The general version of PLS described in this report and used in this study is PLS1 (Wise et al. 2006). When using PLS1, it is necessary to develop separate models for each property of interest (i.e., burnup level or acid concentrations) to extract quantitative information. 


\subsection{Results}

\subsubsection{Non-Optimized Experimental Estimation of MIP Monitor for Determining Acid Concentration}

The first stage of a PUREX type extraction was applied to spent fuel dissolver solution at the hot cell facility in PNNL's Radiochemical Processing Laboratory. After extraction, the organic phase was removed from the hot cells and counted using an HPGe detector. Figure 2.1 shows typical spectra from the organic phase as a function of the acid concentration of the aqueous feed solution. These spectra were mean-centered, normalized, and analyzed using unsupervised PCA. Results from these analyses (shown in Figure 2.2) illustrate that the spectra can be grouped according to acid concentration. Nine replicates at each acid concentration then were used to generate a supervised and calibrated (PLS) PCA model. One replicate at each acid concentration was then treated as an unknown and superimposed on the model to test the ability of the model to predict the acid concentration (Figure 2.3). The root mean squared error of the prediction (RMSEP) is shown in the figure, which is an estimate of the performance of this approach. These preliminary results were limited by the following two major factors: 1) the number of experimental samples available and 2) the linear nature of the PLS model used to predict a nonlinear system. Considering these limitations, this approach was able to predict the acid concentration of the feed from the experimental gamma spectra of the organic phase following extraction to within $\pm 0.1 \mathrm{M}$ at an uncertainty of three sigma.

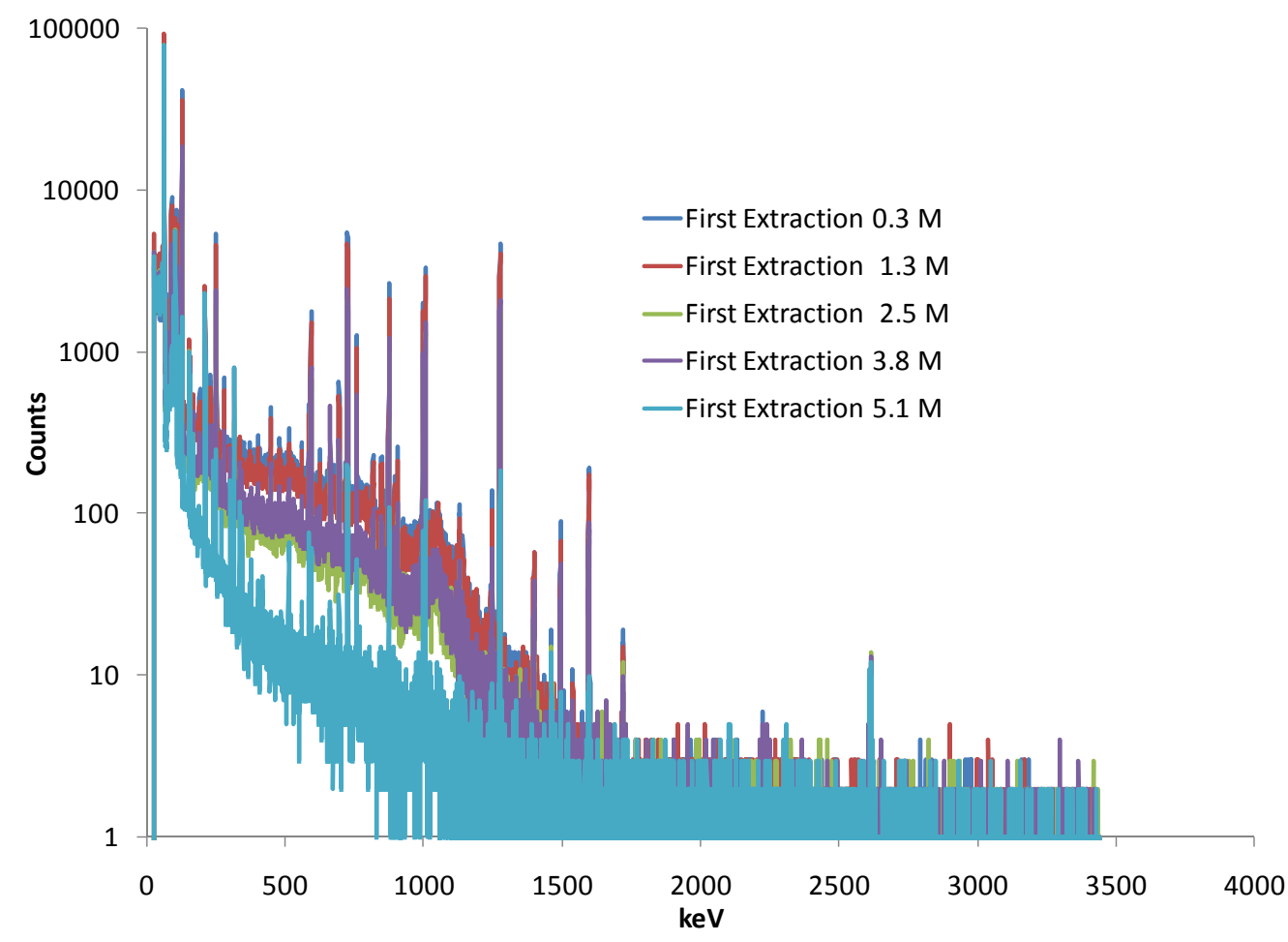

Figure 2.1. Experimental Gamma Spectra Generated from an HPGe Detector for BWR Fuel, 69 to $70 \mathrm{MWd} / \mathrm{kgU}$ And 16-Years Cooled, as a Function of Acid Concentration. 


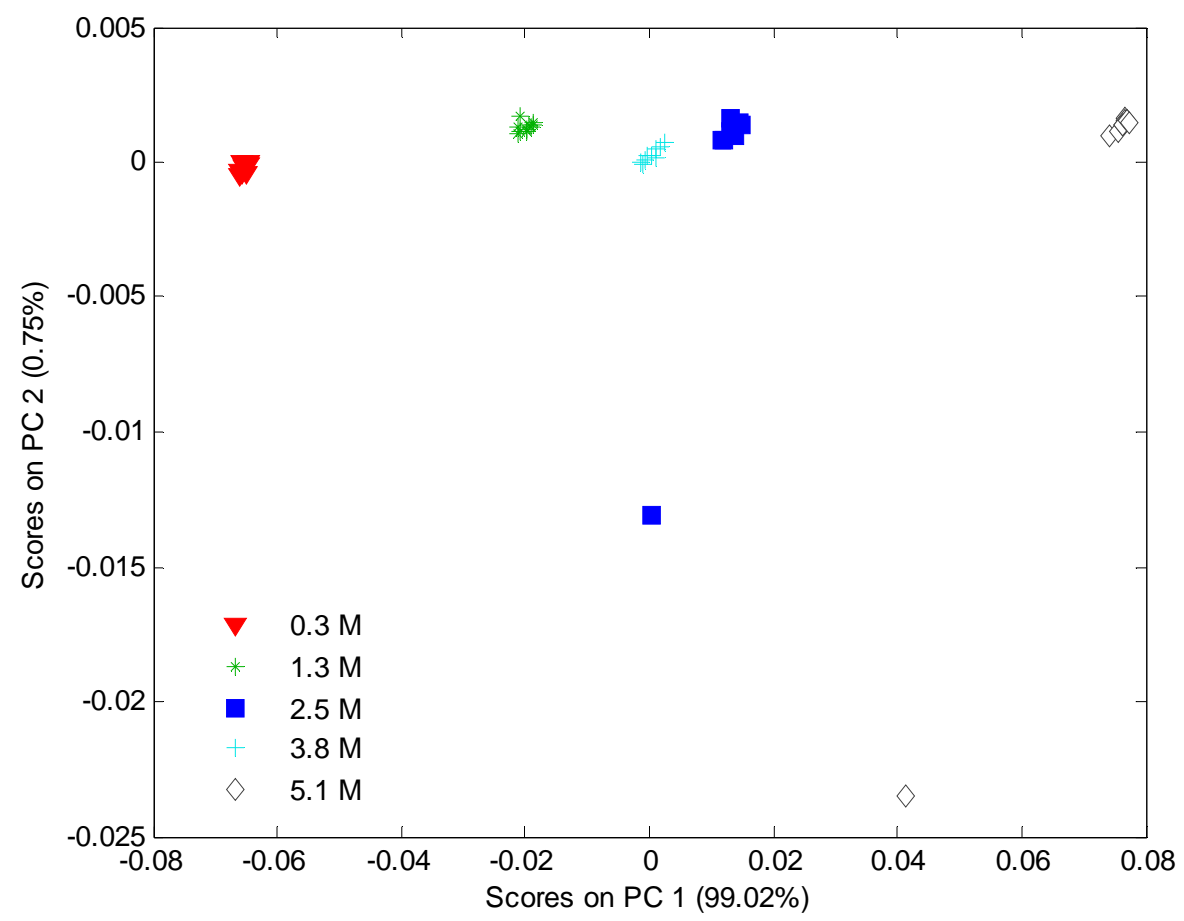

Figure 2.2. PCA Grouping of the Experimental Spectra Shown in Figure 2.1.

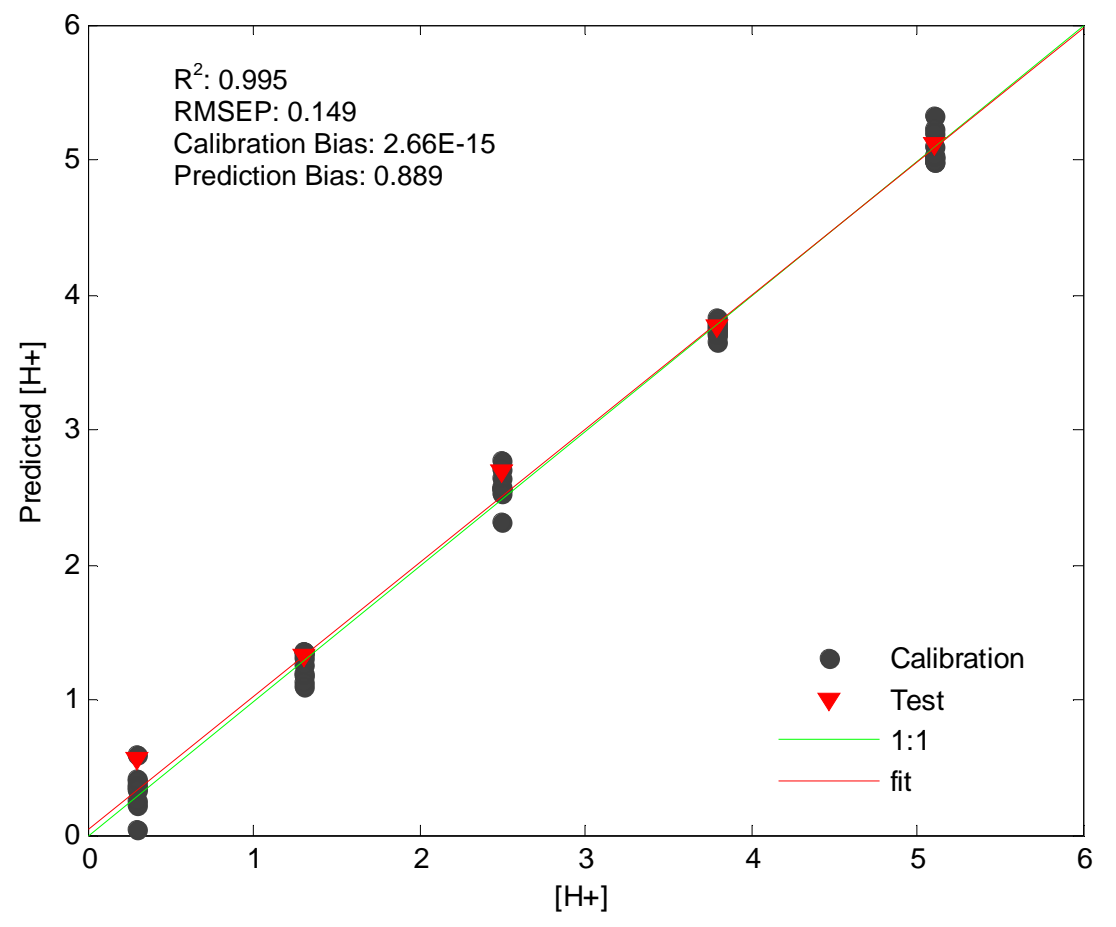

Figure 2.3. PLS Model Results Generated from Data Shown in Figure 2.1. 


\subsubsection{Simulated Sensitivity of the MIP Monitor for Monitoring Acid Concentration}

Simulations designed to mimic experimental investigations described above were conducted. Figure 2.4 shows simulated spectra from the organic phase as a function of the acid concentration of the aqueous feed solution. These spectra were mean-centered, normalized, and analyzed using PLS. Five of these spectra were used to generate a supervised and calibrated (PLS) PCA model. The remaining two spectra were used as unknowns to test the predictive capability of the model (Figure 2.5). The RMSEP is shown in the figure, which is an estimate of the performance of this approach. These simulations suggest the MIP approach, once optimized for a linear PLS model, may be able to predict the acid concentration of the feed using gamma spectra of the organic phase following extraction to within $\pm 0.05 \mathrm{M}$. Data points in Figure 2.5 show some level of nonlinearity, suggesting that a nonlinear model may be more accurate and appropriate for this application.

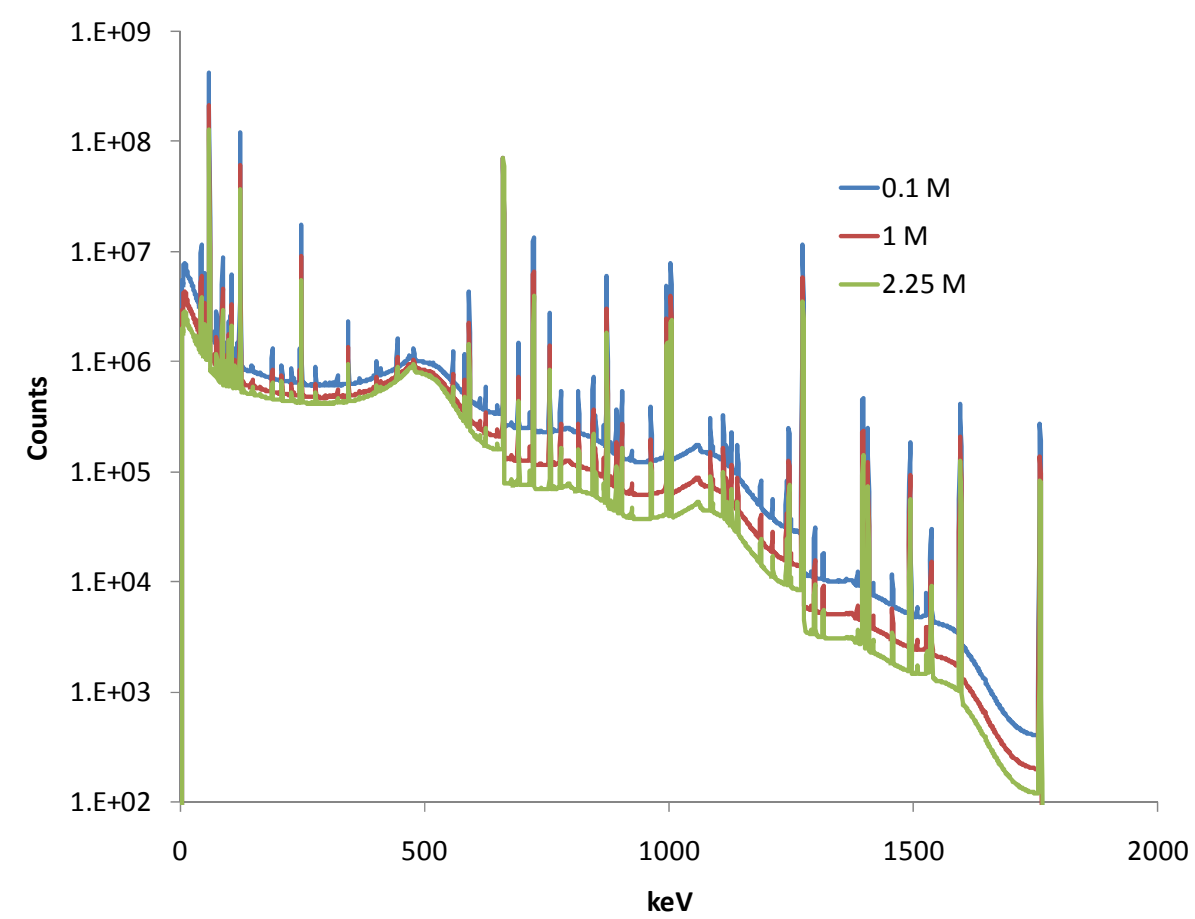

Figure 2.4. Simulated Gamma Spectra Generated From HPGe Detector as a Function of Acid Concentration for Spent BWR Fuel (16 MWd/kgU, 26-Year Cooling). 


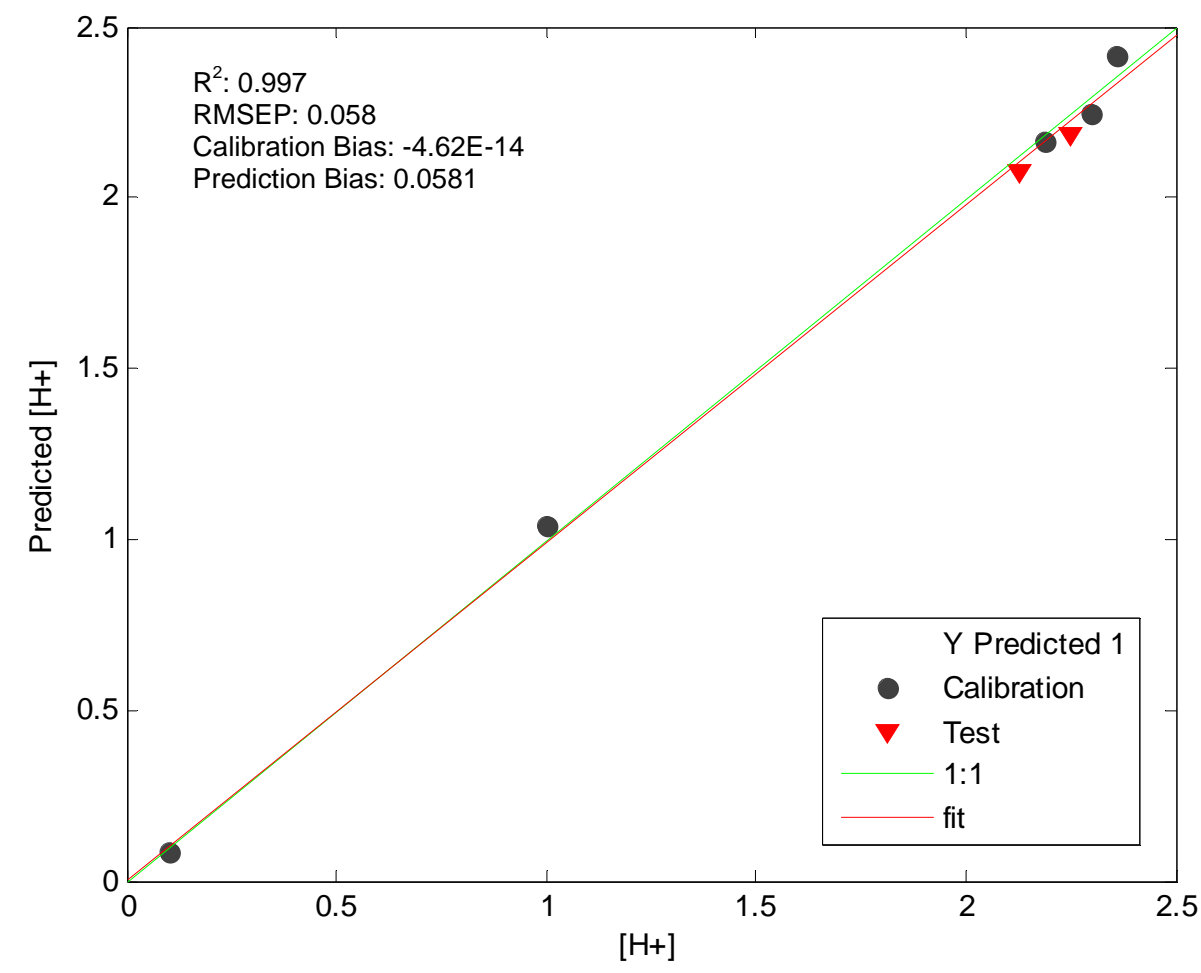

Figure 2.5. PLS Model Results from the Spectra Shown in Figure 2.4.

\subsubsection{Simulated Sensitivity of the MIP Monitor for Determination of Burnup}

Traditional gamma spectrometry has been employed in the past to estimate burnup. However, this technique typically relies on the measurement of the $661-\mathrm{keV}$ cesium-137 line, which in turn depends upon an accurate estimate of the baseline underneath this peak. We hypothesized that the MIP approach may provide a better estimate of burnup by using multiple indicator peaks and more accurately accounting for the unresolved baseline. This hypothesis was tested using simulated gamma spectra of three-year cooled, dissolved, spent fuel taken from a fictitious dissolver tank (shown in Figure 2.6) as a function of burnup. In all samples, nine spectra were generated from simulations. These spectra were mean centered and normalized and then analyzed using unsupervised PCA. Six spectra were then used to generate a supervised and calibrated (PLS) PCA model, while three spectra were treated as unknowns and used to test the model predictive capability. The model developed from spectra that were mean centered and normalized (Figure 2.7) was found to be less accurate than the model based on spectra that simply were mean centered before use (Figure 2.8). This finding indicates that intensity was an important determinant in the model output. The RMSEP is shown in each of the figures. These results suggest the MIP approach could be used to estimate burnup at the dissolver tank to within \pm 0.1 percent of the actual burnup. Model estimates of the MIP performance for this type of application need to be confirmed through experiments. 


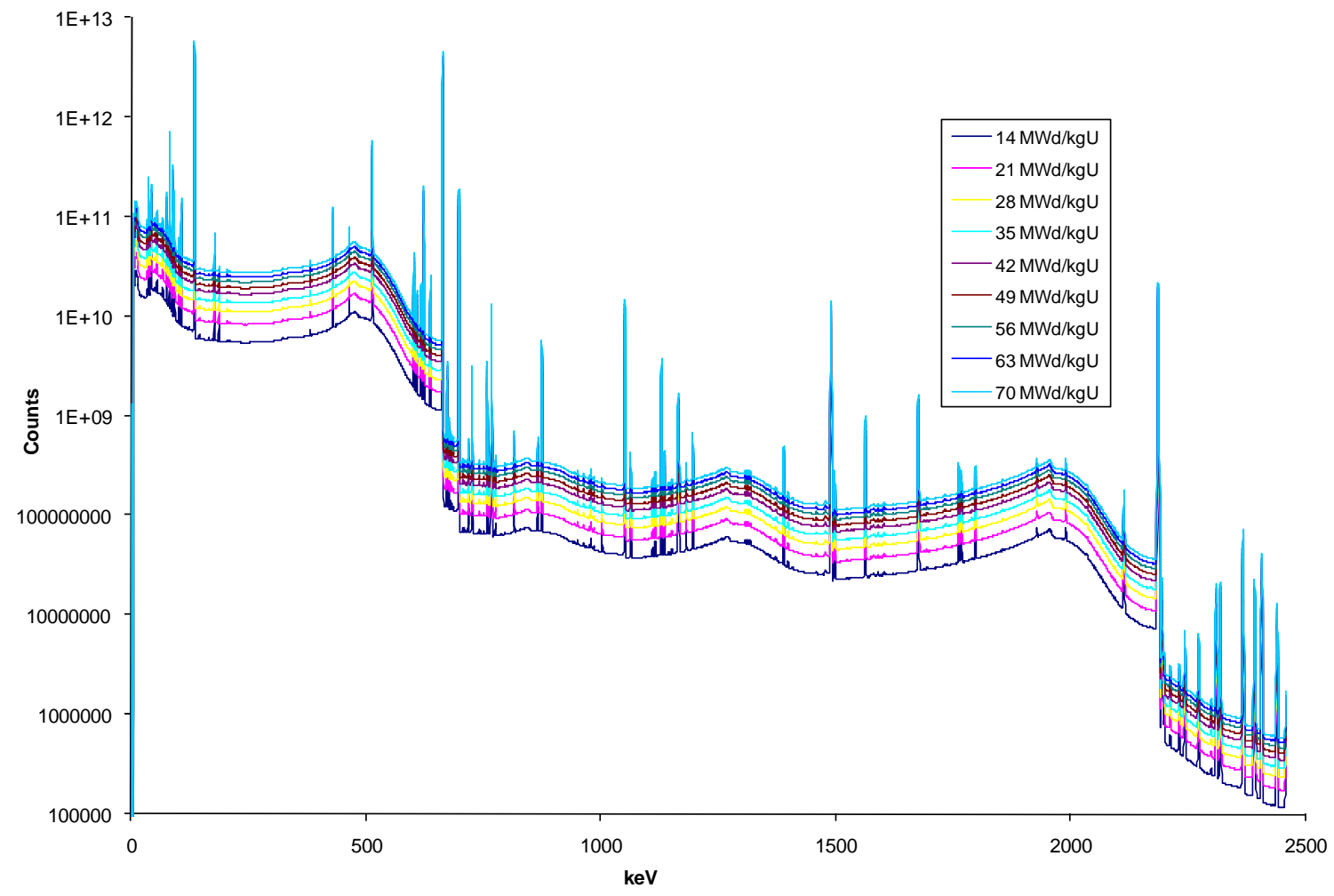

Figure 2.6. Simulated Gamma Spectra of Three-Year Cooled Dissolved Spent Fuel as a Function of Burnup (generated from an HPGe detector).

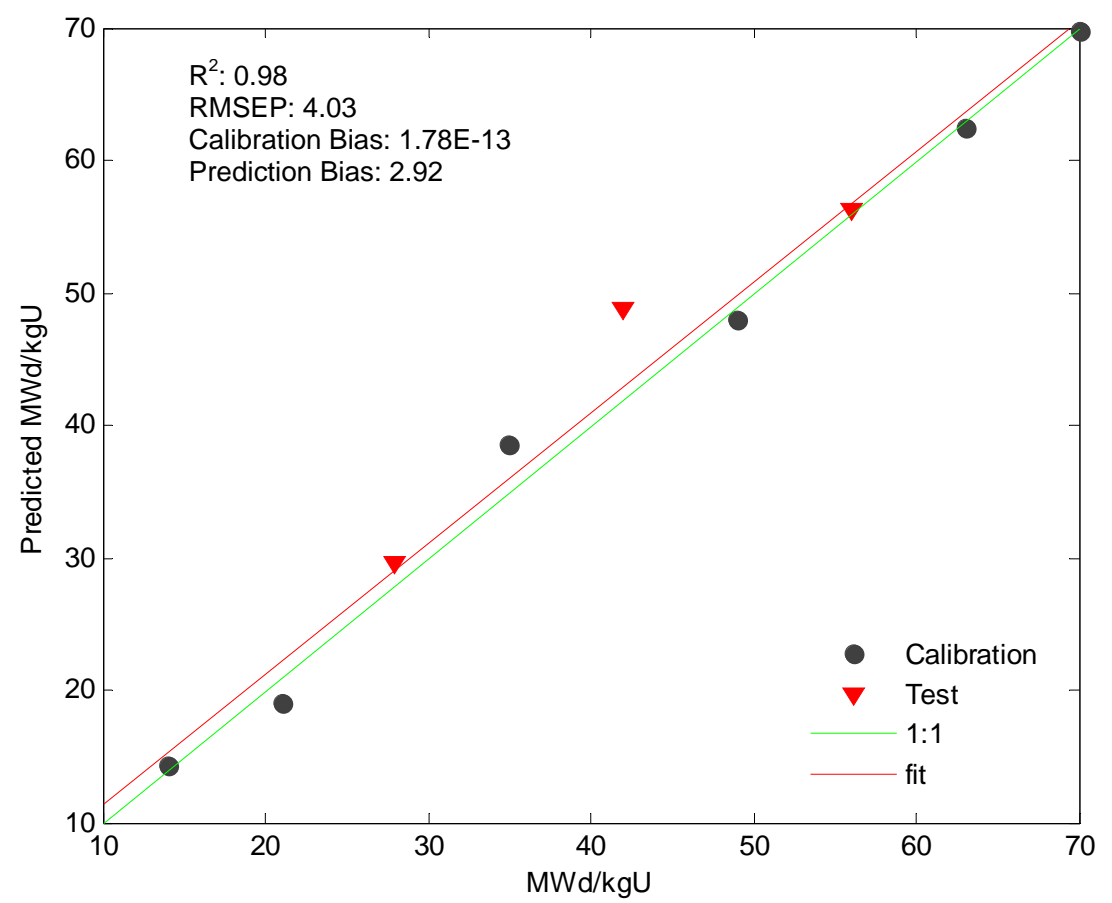

Figure 2.7. PLS Model Results Generated from the Spectra Shown in Figure 2.6 After Mean Centering and Normalization. 


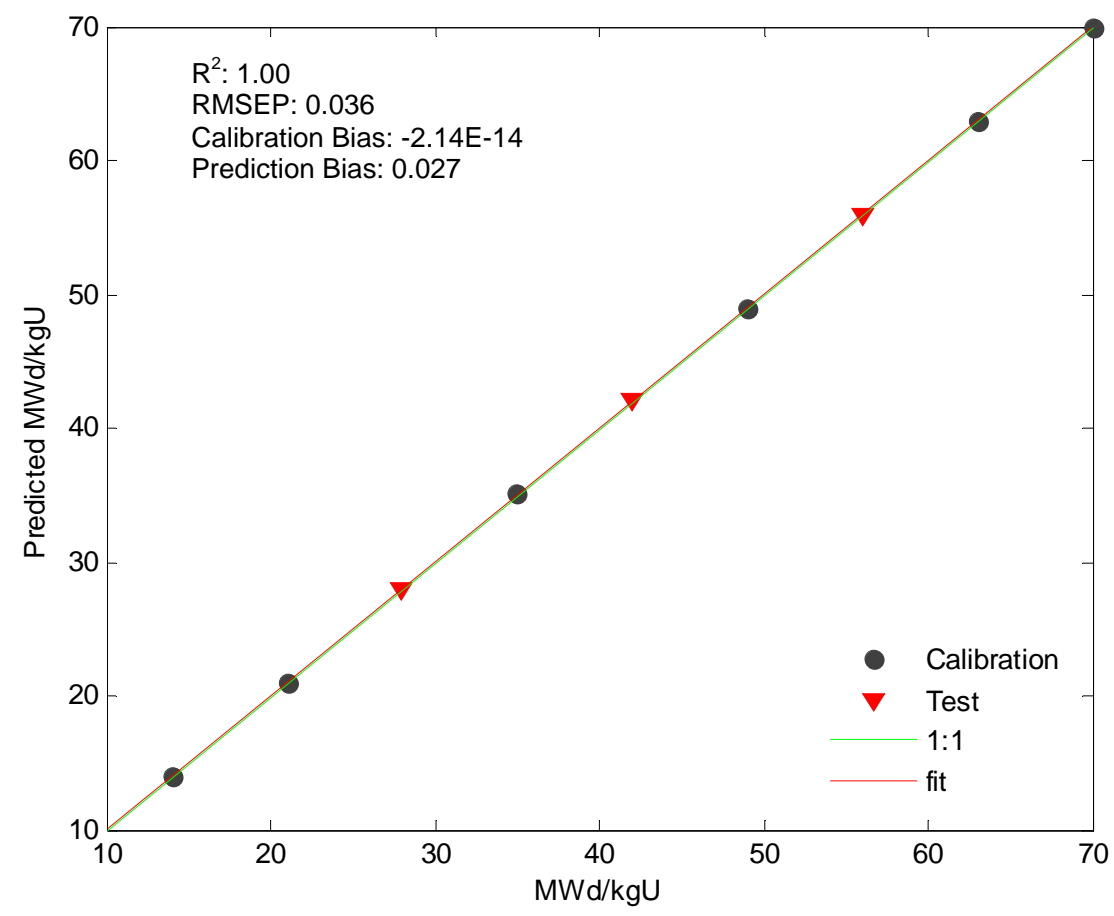

Figure 2.8. PLS Model Results Generated from the Spectra Shown in Figure 2.6 After Mean Centering.

\subsection{Chapter 2 References}

Benedict M, TM Pigford, and HW Levi. 1981. Nuclear Chemical Engineering. $2^{\text {nd }}$ Edition, McGrawHill, New York.

Bromley LA. 1973. "Thermodynamic Properties of Strong Electrolytes in Aqueous Solutions." American Institute of Chemical Engineering Journal 19(1973):313-320.

Croff AG. 1983. "ORIGEN2: A Versatile Computer Code for Calculating the Nuclide Compositions and Characteristics of Nuclear Materials." Nuclear Technology 62(3):335.

Guenther, R. J. et al., "Characterization of Spent Fuel Approved Testing Material - ATM-105," Pacific Northwest Laboratory, PNL-5109-105, June 1989, accessed, October 2008 at http://www.lsnnet.gov/docview.aspx ?mode=1\&lsn=DN2002138631\&ic=1\&im=0\&sc=12\&sm=0

Hensley WK, AD McKinnon, HS Miley, ME Panisko, and RM Savard. 1995. "SYNTH: A Spectrum Synthesizer.” Journal of Radioanalytical and Nuclear Chemistry 193(2):229-237.

Ishimori T and K Watanabe. 1960. "Inorganic Extraction Studies on the System of Tri-n-Butyl Phosphate-Nitric Acid.” Bulletin of the Chemical Society of Japan 33(10):1443-1448.

Leonard RA and MC Regalbuto. 1994. "A Spreadsheet Algorithm for Stagewise Solvent-Extraction." Solvent Extraction and Ion Exchange 12(5):909-930.

Malinowski E. 2008. Factor Analysis in Chemistry. John Wiley \& Sons, New York. 
Matlab. 2009. Version 7.8.0.347 (R2009a). The MathWorks, Inc, Natick, Massachusetts.

Orton CR, JM Schwantes, S Bryan, T Levitskaia, D Duckworth, M Douglas, OT Farmer, C Fraga, S Lehn, M Liezers, S Peper, and RN Christensen. 2008. "Advanced Safeguards Technology Demonstration at Pacific Northwest National Laboratory" In Proceedings of the $49^{\text {th }}$ Annual INMM Conference, Nashville, Tennessee.

PLS_Toolbax. 2008. Version 5.0 for use with MATLAB, Eigenvector Research, Inc, Wenatchee, Washington.

Regalbuto MC, JM Copple, R Leonard, C Pereira, and GF Vandegrift. 2005. "Solvent Extraction Process Development for Partitioning and Transmutation of Spent Fuel." In Proceeding of the $8^{\text {th }}$ Information Exchange Meeting on Actinide and Fission Product Partitioning and Transmutation:, Las Vegas, Nevada, United States, November 9-1, pp. 373-385, 2004; (C) Organization for Economic Cooperation and Development, Nuclear Energy Agency (OECD-NEA): Paris, France, 2005. Accessed at http://www.nea.fr/html/pt/docs/iem/lasvegas04/posterI.html during October 2009.

Schwantes JM, M Douglas, CR Orton, C Fraga, and RN Christensen. 2008. "Multi-Isotope Process (MIP) Monitor: a Near-Real-Time Monitor for Reprocessing Facilities" ANS Transactions from the Annual Meeting, Anaheim, California.

Smith LE, JM Schwantes, JJ Ressler, M Douglas, KA Anderson, CG Fraga, PC Durst, CR Orton, and RN Christensen. 2007. "Next Generation Online MC\&A Technologies for Reprocessing Plants." In Proceedings of Global 2007: Advanced Nuclear Fuel Cycles and Systems, September 9-13, 2007, Boise, Idaho.

Vaidyanathan S, RD Reager, RW Warner, et al. 1997. "High Burnup BWR Fuel Pellet Performance." In American Nuclear Society, Proceedings of the International Topical Meeting on Light Water Reactor Fuel Performance, p. 471, March 2-6, 1997, Portland, Oregon.

Vandegrift GF, DB Chamberlain, C Conner, JM Copple, JA Dow, L Everson, JC Hutter, RA Leonard, L Nunez, MC Regalbuto, J Sedlet, B Srinivasan, S Weber, and DG Wygmans. 1993. "Development and Demonstration of the TRUEX Solvent Extraction Process." In Proceedings of the Symposium on Waste Management, pp. 1045-1050, February 28-March 4, 1993, Tucson, Arizona.

Wise BM, et al. 2006. PLS_Toolbax Version 4.0 for use with MATLAB, Manual. Eigenvector Research, Inc, Wenatchee, Washington.

Wolf SF, DL Bowers, and JC Cunnane. 2005. “Analysis of High Burnup Spent Nuclear Fuel by ICPMS.” Journal of Radioanalytical and Nuclear Chemistry 263(3): 581-586. 



\title{
3.0 FY 2009 Progress: Spectroscopy-Based Monitoring
}

\author{
Sam A Bryan, ${ }^{1}$ Tatiana G Levitskaia, ${ }^{1}$ James M. Peterson, ${ }^{1}$ \\ Amanda J. Casella, ${ }^{1}$ Elizabeth M Thomas, ${ }^{2}$ and Amanda M. Lines ${ }^{3}$
}

\subsection{Introduction}

Advanced techniques that enhance safeguarding of spent fuel reprocessing plants are urgently needed. Our approach is based on the prerequisite that real-time monitoring of solvent extraction flowsheets at a spent fuel reprocessing plant provides the unique capability to quickly detect unwanted manipulations with fissile isotopes present in the radiochemical streams during reprocessing activities. The methods used to monitor these processes must be robust and capable of withstanding harsh radiation and chemical environments.

On-line monitoring of nuclear waste streams was successfully demonstrated by combining spectroscopic measurements with physiochemical measurements (conductivity, density, and temperature) in the real-time quantitative determination of chemical components found in the waste (Bryan et al. 2005, 2008). This new on-line monitoring system, which features Raman spectroscopy combined with a Coriolis meter and a conductivity probe, recently was developed by our research team to provide immediate chemical data and flow parameters of high-level radioactive waste streams. This process monitoring system has been used to measure the concentration of components of high brine/high alkalinity waste solutions, such as nitrate, nitrite, chromate, aluminate, phosphate, sulfate, carbonate, and hydroxide, during retrieval from Hanford waste storage tanks. The Raman bands of interest for these species are well resolved and have been easily incorporated into a chemometric model for quantitative analysis of the solution components.

By inclusion of Vis-NIR spectrophotometer, this robust system was modified to monitor spent fuel reprocessing streams (Bryan et al. 2007). A key advantage of using a fiber optic Raman probe is that it allows the monitoring of various species encountered in both aqueous and organic phases. Raman active species include: 1) metal oxide ions, such as uranyl, neptunyl, and pertechnetate ions, 2) organics, and 3) inorganic oxo-anions and water. The trivalent and tetravalent actinides and lanthanides in both the aqueous and organic phases can be monitored by Vis-NIR spectroscopy, as would pentavalent or hexavalent neptunium and plutonium that are expected to be at concentrations too low to be determined by Raman spectroscopy. Process monitoring and control is feasible at various points within fuel reprocessing facilities.

The Raman and Vis-NIR spectrometers used under laboratory conditions are easily augmented to process-friendly configurations, allowing remote measurements under dynamic flow conditions using different sampling capabilities such as fiber-optic probes, dip probes, and flow-through cell geometries. In last years summary report, we presented our results on spectroscopic measurements of simulant flowsheet solutions and actual commercial fuel solutions designed to demonstrate the applicability of Raman and Vis-NIR spectroscopic analysis for process monitoring. In this report, we present results of

\footnotetext{
${ }^{1}$ Radiochemical Processing Laboratory, Pacific Northwest National Laboratory, Richland, Washington

${ }^{2}$ NSIP Student Intern, University of Michigan, Ann Arbor, Michigan

${ }^{3}$ NSIP Student Intern, Purdue University, West Lafayette, Indiana
} 
detection limit measurements for $\mathrm{UO}_{2}{ }^{2+}$, plutonium(IV), neptunium(V) and neptunium(VI) under flowsheet conditions, as well as the relative standard deviation associated with each measurement in order to assess the viability of also using this technology for nuclear material accountancy measurements.

\subsection{Experimental}

Raman spectra were collected on an InPhotonics Inc. RS2000 echelle spectrograph. The system was equipped with a stabilized $670-\mathrm{nm}, 150-\mathrm{mW}$ visible diode laser as the excitation source. Data were collected at $1 \mathrm{~cm}^{-1}$ spectral resolution over a range of 200 to $4000 \mathrm{~cm}^{-1}$ stokes shift (Raman shift from $670 \mathrm{~nm}$ ). Samples were measured with an InPhotonics focused fiber optic probe (RamanProbe ${ }^{\mathrm{TM}}$ ) with a thermoelectrically-cooled charge-coupled device detector, normal operating temperature $-55^{\circ} \mathrm{C}$. The laser beam was coupled to the sample through a 10-m fiber-optic cable and probe assembly, which focused the excitation beam directly into the sample; this approach also precluded any air gap between the laser source and the sample. The focal point of the laser beam was $5 \mathrm{~mm}$ beyond the end of the laser probe tip, the measured laser intensity at the sample was typically $50 \mathrm{~mW}$, and the excitation laser beam diameter at the sample was measured as $3 \mathrm{~mm}$. Molecule ${ }^{\circledR}$ acquisition software with GRAMS $32^{\circledR}$ data manipulation software was used to process the Raman data. Typically, an integration time of 2 to 20 seconds was used for each acquisition. Visible-near infrared (VIS-NIR) measurements of plutonium (IV) solutions were performed using a 400 series dual source reflectance fiber optic probe (SI Photonics) coupled with an LS1 tungsten halogen light source (Ocean Optics) and an USB2000-VIS-NIR spectrophotometer (Ocean Optics).

\subsection{Process Monitoring Instrumentation}

\subsubsection{Uranium (VI) Analysis}

A series of simulant feed solutions containing 0.1 to $1.3 \mathrm{M} \mathrm{UO}_{2}\left(\mathrm{NO}_{3}\right)_{2}$ in $3.0 \mathrm{M} \mathrm{HNO}_{3}$ was prepared and subjected to Raman measurements. The obtained spectral overlay is shown in Figure 3.1. A linear relationship was observed between the Raman response of the respective $\mathrm{UO}_{2}{ }^{2+}\left(870 \mathrm{~cm}^{-1}\right)$ and $\mathrm{NO}_{3}{ }^{-}$ $\left(1047 \mathrm{~cm}^{-1}\right)$ bands and the concentration of $\mathrm{UO}_{2}\left(\mathrm{NO}_{3}\right)_{2}$ as shown in Figure 3.2. An International Union of Pure and Applied Chemistry (IUPAC)-recommended treatment was used to evaluate the detection limit (Long and Winefordner, 1983) of this spectroscopic technique. In this treatment, the detection limit is calculated using eq 3.1:

$$
D L=\frac{k S_{b}}{m+t S_{m}}
$$

where DL is detection limit; $k$ is a numerical coefficient; $m$ is the slope; $S_{\mathrm{b}}$ and $S_{\mathrm{m}}$ are the standard errors for the intercept and slope of a calibration plot, respectively; and $t$ is the Student's value for $(n-2)$ degrees of freedom at the chosen confidence level. In accord with IUPAC recommendations, a $k$ value of 3 was applied which in turn calls for a 99.87 percent confidence level. This confidence level was used in the linear regression analysis, and the denominator in eq 3.1 was taken as the upper 99.87 percent value of the slope. This treatment yielded a detection limit of $3.1 \mathrm{mM}$ for $\mathrm{UO}_{2}{ }^{2+}$ under applied measurement conditions. 
A series of Raman spectral measurements were performed overnight on a single solution containing $1 \mathrm{M} \mathrm{UO}_{2}\left(\mathrm{NO}_{3}\right)_{2}$ in $3.0 \mathrm{M} \mathrm{HNO}_{3}$. The series is shown in Figure 3.3 and represents 3800 individual spectra taken over the 21.1 hour time span. The Raman spectral data were subjected to chemometric analysis using the data in Figure 3.1 as the training set on which to base the quantitative analysis. The results of the analysis yielded a mean concentration of $1.042 \mathrm{M} \mathrm{UO}_{2}{ }^{2+}$ with a standard deviation of \pm 0.009 , which represents a 0.82 percent relative standard deviation for the $\mathrm{UO}_{2}{ }^{2+}$ measurement.

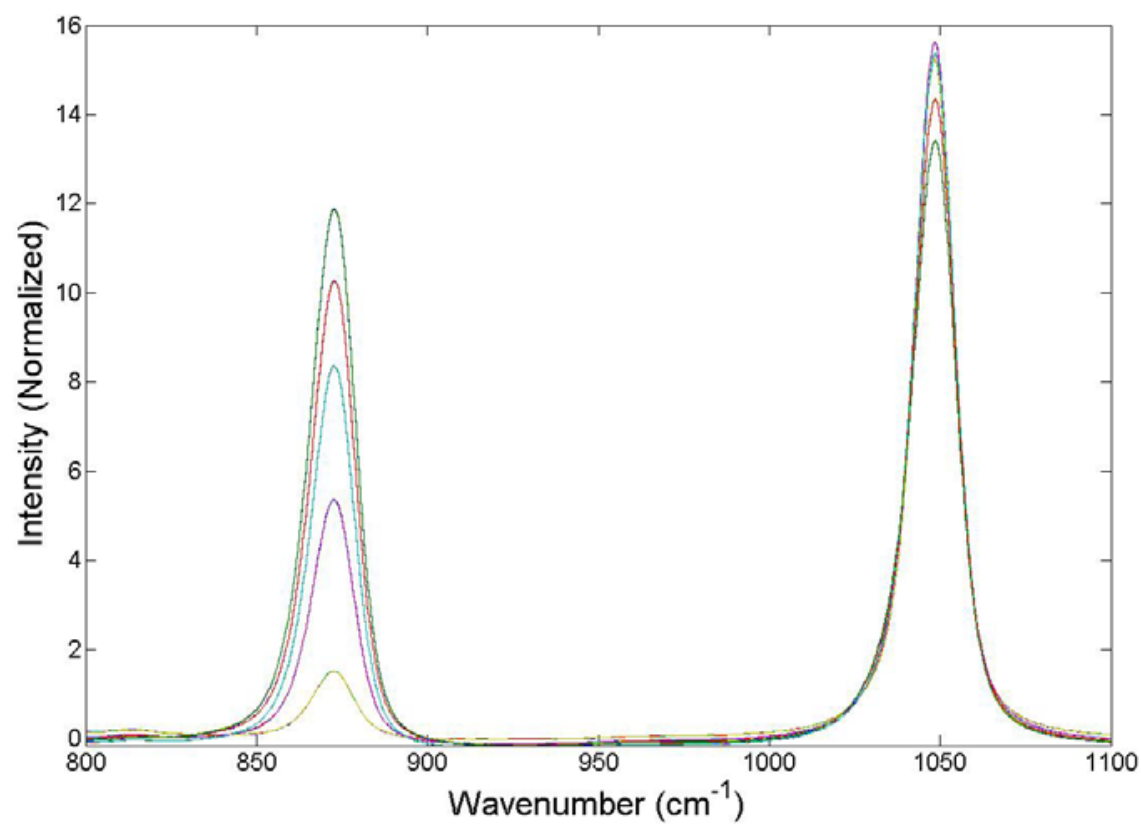

Figure 3.1. Representative Spectra of Variable $\mathrm{UO}_{2}\left(\mathrm{NO}_{3}\right)_{2}$ Concentration in $3.0 \mathrm{M} \mathrm{HNO}_{3}$.

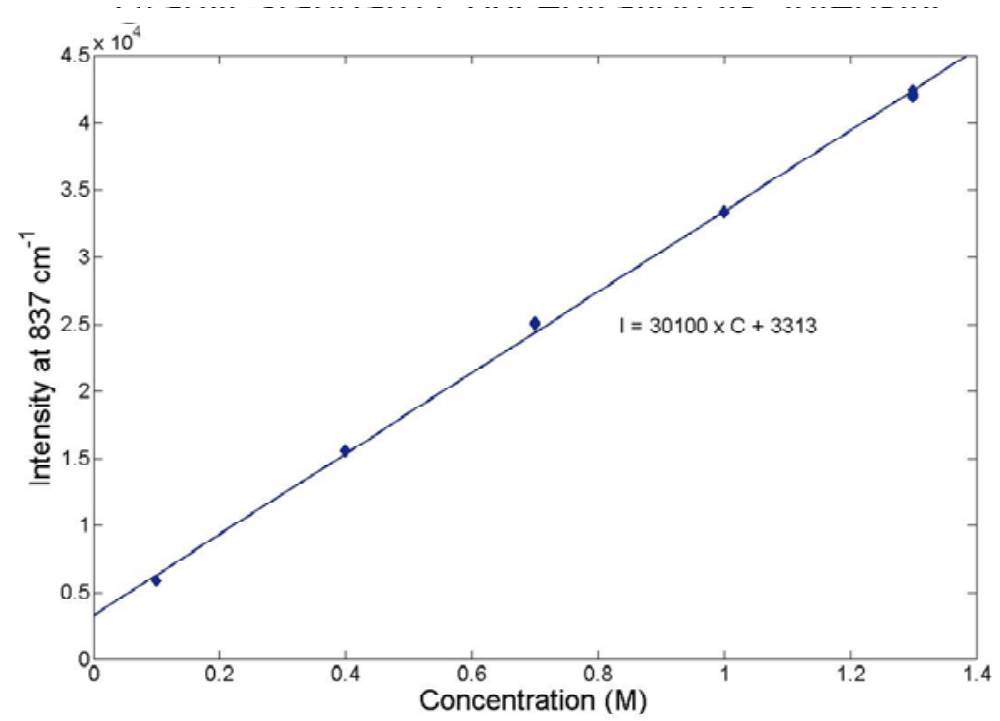

Figure 3.2. Raman Response $\left(870 \mathrm{~cm}^{-1}\right)$ versus $\mathrm{UO}_{2}{ }^{2+}$ Solution Concentration. 


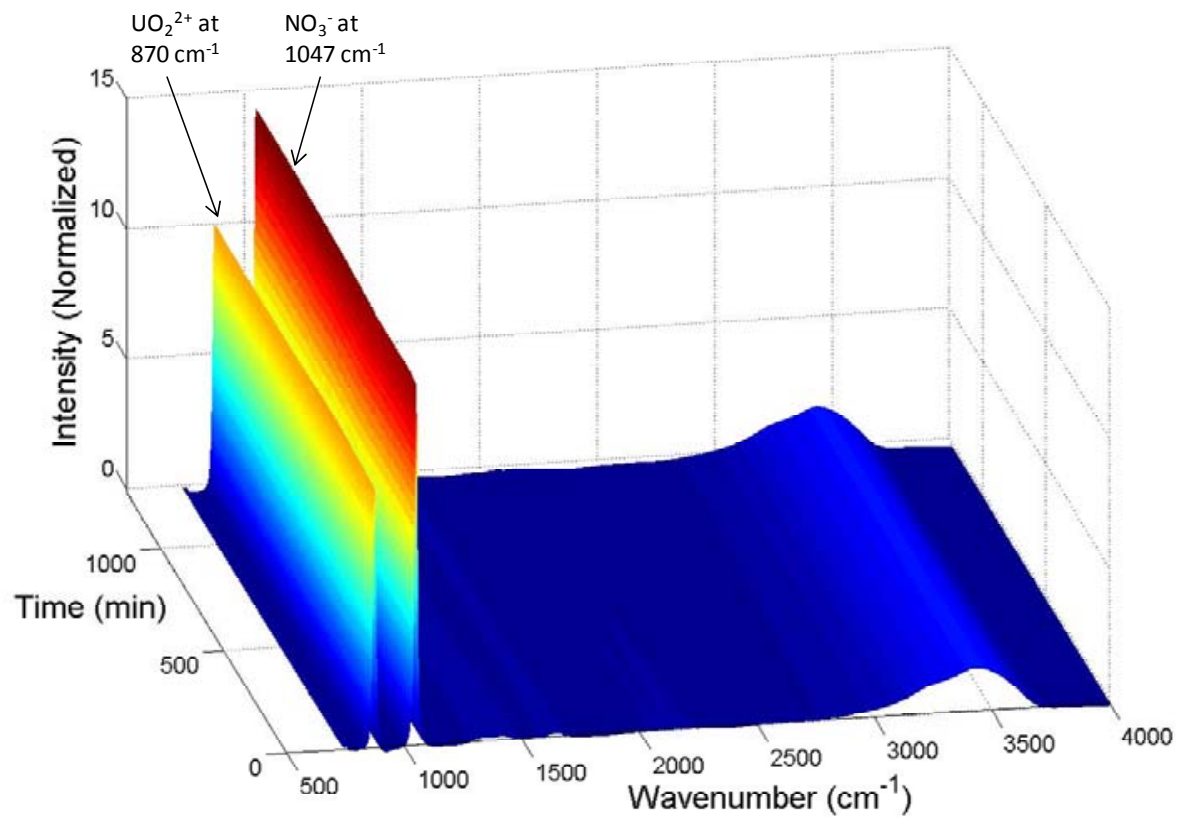

Figure 3.3. Sample Spectra of $\mathrm{UO}_{2}\left(\mathrm{NO}_{3}\right)_{2}$ in Nitric Acid Measured as a Function of Time.

\subsubsection{Plutonium (IV) Analysis}

A series of simulant feed solutions containing 0.1 to $10 \mathrm{mM} \mathrm{Pu}$ (IV) in a matrix of $1.33 \mathrm{M} \mathrm{UO}_{2}\left(\mathrm{NO}_{3}\right)_{2}$ and $0.8 \mathrm{M} \mathrm{HNO}_{3}$ was prepared and immediately subjected to VIS-NIR measurements. The obtained spectral overlay is shown in Figure 3.4. It was observed that plutonium (IV) spectral features from 600 to $900 \mathrm{~nm}$ were not obstructed by spectroscopic features of $\mathrm{UO}_{2}\left(\mathrm{NO}_{3}\right)_{2}$ or $\mathrm{HNO}_{3}$ allowing linear calibration plots to be obtained using four characteristic plutonium (IV) bands in this region (Figure 3.5). The detection limit for plutonium (IV) was determined to be $0.08 \mathrm{mM}$ using the $659 \mathrm{~nm}$ band, using the IUPAC- recommended treatment discussed above. 


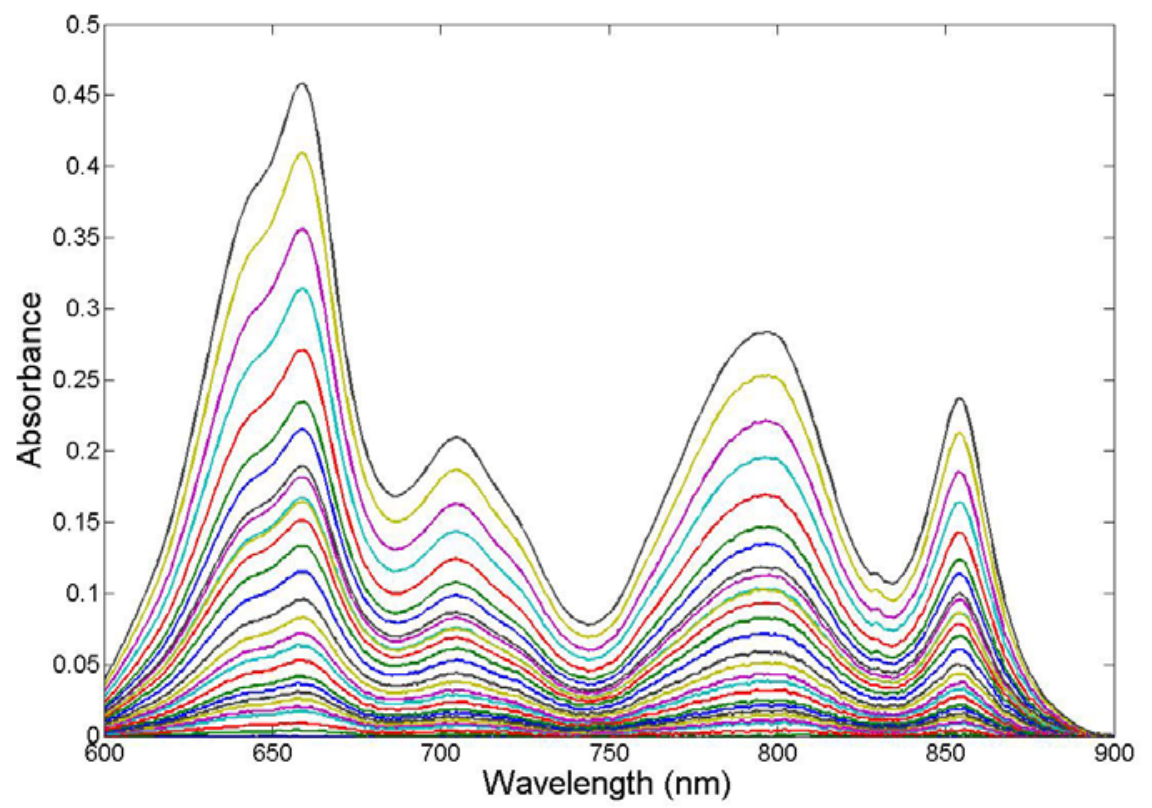

Figure 3.4. Baseline-corrected VIS-NIR spectra for $\mathrm{Pu}(\mathrm{IV})$ in $1.33 \mathrm{M} \mathrm{UO}_{2}\left(\mathrm{NO}_{3}\right)_{2}$ and $0.8 \mathrm{M} \mathrm{HNO}_{3}$.

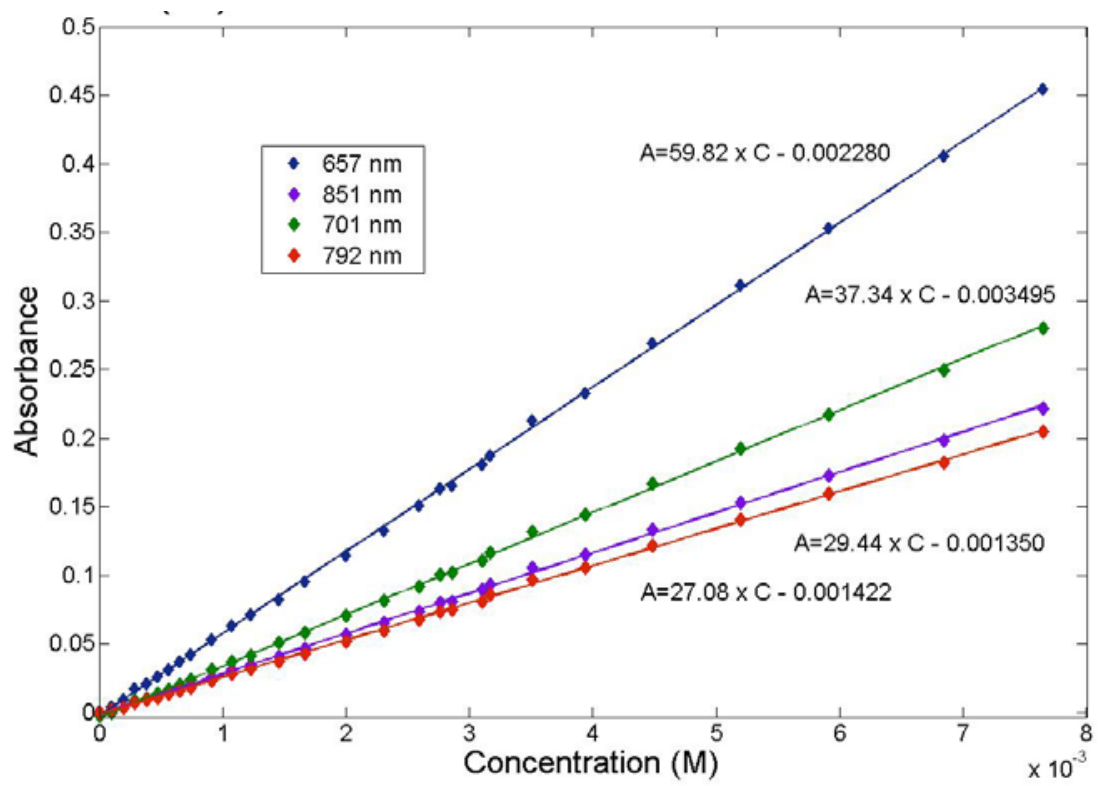

Figure 3.5. Calibration Plots for the Baseline-Corrected Plutonium (IV) Absorbance Spectra Shown in Figure 3.4.

A series of VIS-NIR spectral measurements were performed for an extended period of approximately 1 hour using a single solution containing approximately $0.9 \mathrm{mM} \mathrm{Pu}\left(\mathrm{NO}_{3}\right)_{4}$ in $1.33 \mathrm{M} \mathrm{UO}_{2}\left(\mathrm{NO}_{3}\right)_{2}$ and $0.8 \mathrm{HNO}_{3}$. The series shown in Figure 3.6 represents 230 individual spectra taken over the 1 hour time span. The VIS-NIR spectral data were subjected to chemometric analysis using the data in Figure 3.4 as the training set on which to base the quantitative analysis. The results of the analysis yielded a mean concentration of $0.928 \mathrm{mM}$ plutonium (IV) with a standard deviation of $\pm 0.016 \mathrm{mM}$, which represents a 1.7 percent relative standard deviation for the plutonium (IV) measurement. 


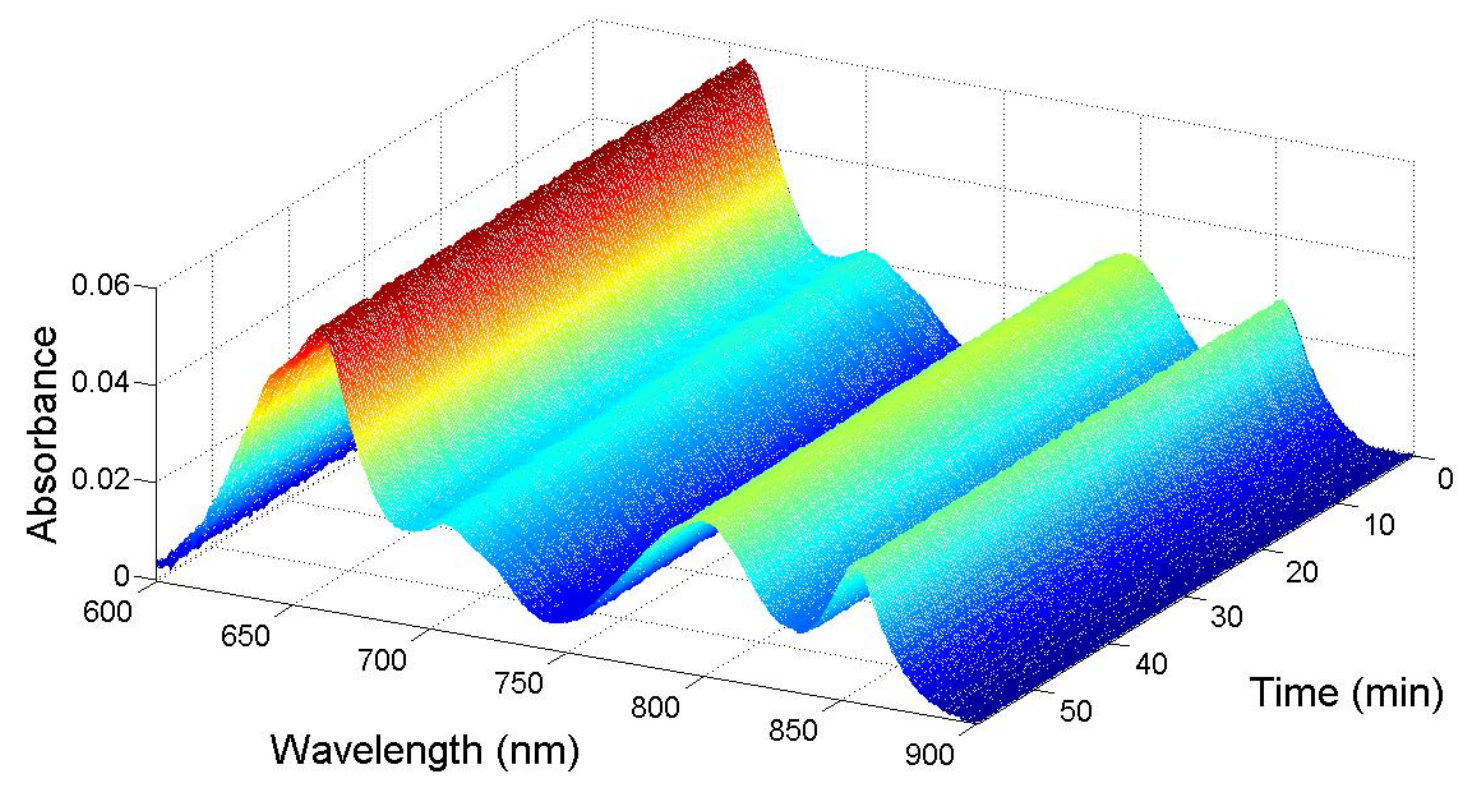

Figure 3.6. Sample Spectra for a Solution of Approximately $0.9 \mathrm{mM} \mathrm{Pu}\left(\mathrm{NO}_{3}\right)_{4}$ in a Matrix of $1.33 \mathrm{M}$ $\mathrm{UO}_{2}\left(\mathrm{NO}_{3}\right)_{2}$ and $0.8 \mathrm{HNO}_{3}$.

\subsubsection{Neptunium (V, VI) Analysis}

Neptunium is present in the dissolved spent fuel predominantly as neptunium (V) in the $\mathrm{NpO}_{2}{ }^{+}$ chemical form. However, its redox equilibrium $\mathrm{Np}(\mathrm{IV}) \Leftrightarrow \mathrm{Np}(\mathrm{V}) \Leftrightarrow \mathrm{Np}(\mathrm{VI})$ highly depends on multiple factors including solution composition, temperature, etc. (Bürck 1991). This redox chemistry determines neptunium distribution into the TBP/dodecane phase and its monitoring is desirable from a safeguards perspective because it is needed for flowsheet verification. The aqueous speciation of neptunium (V) is complex because of its coordination with nitrate anion and the formation of cation-cation complexes in accord with reactions 3.2 and 3.3 (Colston et al. 2001):

$$
\begin{aligned}
& \mathrm{NpO}_{2}^{+}+\mathrm{n} \mathrm{NO}_{3}^{-} \Leftrightarrow\left(\mathrm{NpO}_{2}{ }^{+} \cdot \mathrm{n} \mathrm{NO}_{3}{ }^{-}\right) \\
& \mathrm{NpO}_{2}{ }^{+}+\mathrm{M}^{\mathrm{n}+} \Leftrightarrow\left(\mathrm{NpO}_{2}{ }^{+} \cdot \mathrm{M}^{\mathrm{n}+}\right)
\end{aligned}
$$

where $\mathrm{M}^{\mathrm{n}+}$ is a transition or $\mathrm{f}-$ metal cation. In dissolved spent fuel, the complex species $\mathrm{NpO}_{2}{ }^{+} \cdot \mathrm{UO}_{2}{ }^{2+}$ is known to form and can be described by reaction 3.4.

$$
\mathrm{NpO}_{2}^{+}+\mathrm{UO}_{2}^{2+} \Leftrightarrow\left(\mathrm{NpO}_{2}^{+} \cdot \mathrm{UO}_{2}^{2+}\right)
$$

The splitting of the single characteristic $\mathrm{NpO}_{2}{ }^{+}$band at $981 \mathrm{~nm}$, commonly observed in $1 \mathrm{M} \mathrm{HNO}_{3}$ solution, into two bands occurs in the presence of uranium (VI) at concentrations typically found in dissolved spent fuel streams. As a result, neptunium (V) spectroscopic properties are highly mobile and dependent on solution composition. To this end, understanding and quantification of neptunium (V) chemistry is needed to correctly interpret its VIS-NIR spectra. 
To investigate the spectral nature of neptunium in the UREX+ process, a series of solutions of variable neptunium (V) concentration in $1.33 \mathrm{M} \mathrm{UO}_{2}\left(\mathrm{NO}_{3}\right)_{2}$ and $0.8 \mathrm{M} \mathrm{HNO}_{3}$ were prepared; the VIS-NIR spectra are shown in Figure 3.7 (left). Two bands are observed for the neptunium (V) in the UREX feed solution, a result of the equilibrium between two neptunium solution species, the free neptunium (V) and a cation-cation interaction complex between neptunium (V) and $\mathrm{UO}_{2}{ }^{2+}(981 \mathrm{~nm}$ and $998 \mathrm{~nm}$ respectively) (Steele and Taylor 2007). Figure 3.7 (right) shows the calibration curves for the neptunium (V) VIS-NIR data in simple feed solution shown in Figure 3.7 (left). The detection limit for neptunium (V) was estimated to be $0.1 \mathrm{mM}$ with the $981 \mathrm{~nm}$ band, using the IUPAC-recommended treatment discussed above.

A series of neptunium solutions ranging in concentration from 0 to $0.1 \mathrm{mM} \mathrm{Np}(\mathrm{V})$; and 0 to $0.75 \mathrm{mM} \mathrm{Np}(\mathrm{VI})$, each containing $6.0 \mathrm{M} \mathrm{HNO}_{3}$ were prepared and subjected to VIS-NIR measurement. The obtained spectral overlay is shown in Figure 3.8. The linear calibration plots were obtained using the characteristic neptunium (V) and neptunium (VI) bands at 980 and $1220 \mathrm{~nm}$, respectively (Figure 3.9). A series of VIS-NIR spectral measurements were performed for an extended period of approximately 8 hours using one solution containing a mix of neptunium (V) and neptunium (VI) oxidation states. The series of spectra are shown in Figure 3.10 representing 2010 individual spectra taken over the 8-hour time span. The VIS-NIR spectral data were subjected to chemometric analysis using the data in Figure 3.8 as the training set on which to base the quantitative analysis. The results of the analysis yielded a mean concentration of $0.092 \pm 0.005 \mathrm{mM}$ for neptunium $(\mathrm{V})$ and $0.910 \pm 0.010 \mathrm{mM}$ for neptunium (VI), which represents a 5.6 and 1.08 percent relative standard deviation for neptunium (V) and neptunium (VI) measurement, respectively.
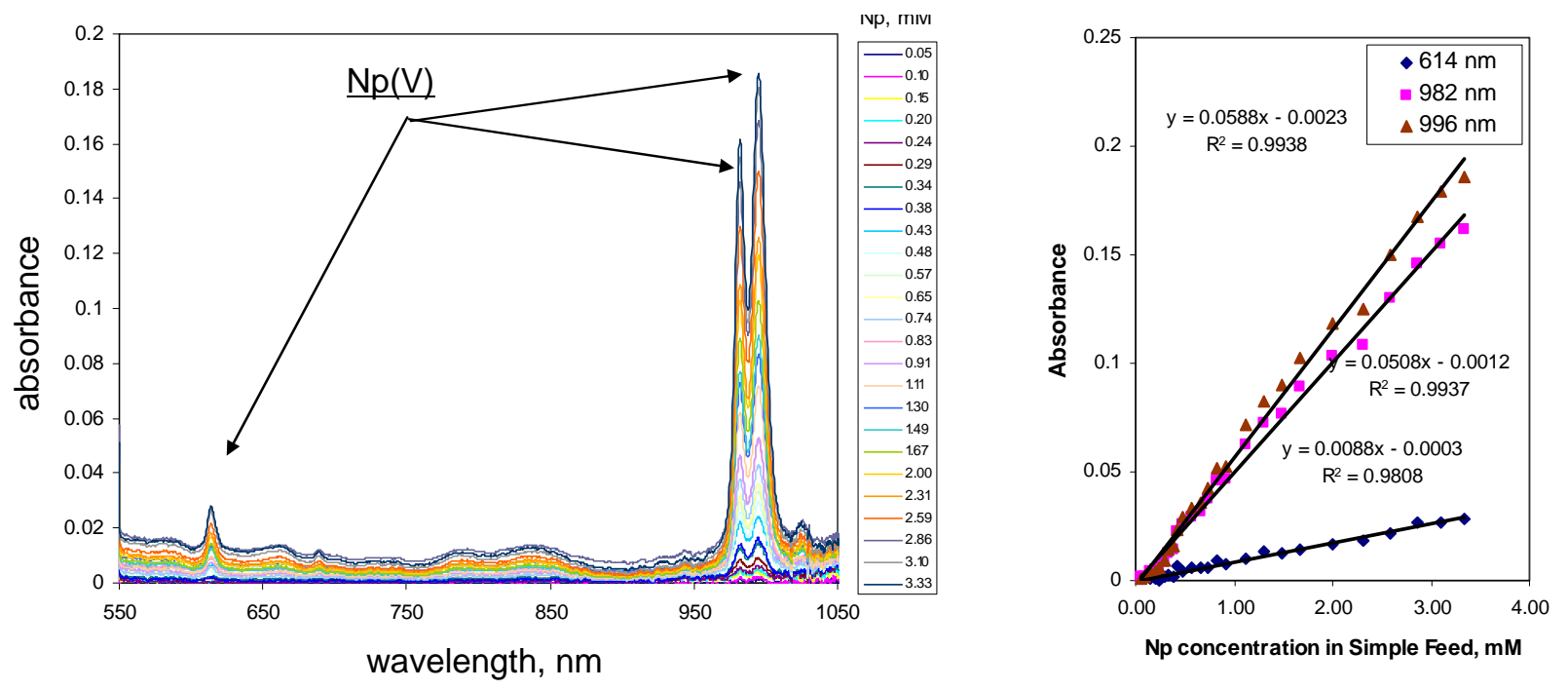

Figure 3.7. (left) Spectra of Neptunium (V) Added to Fuel Feed Simulant. Feed composition: $1.3 \mathrm{M}$ $\mathrm{UO}_{2}\left(\mathrm{NO}_{3}\right)_{2}$ in $0.8 \mathrm{M} \mathrm{HNO}_{3}$. (right) Linear Calibration Curve of Neptunium (V) VIS-NIR Data in Simple Feed Solution. 


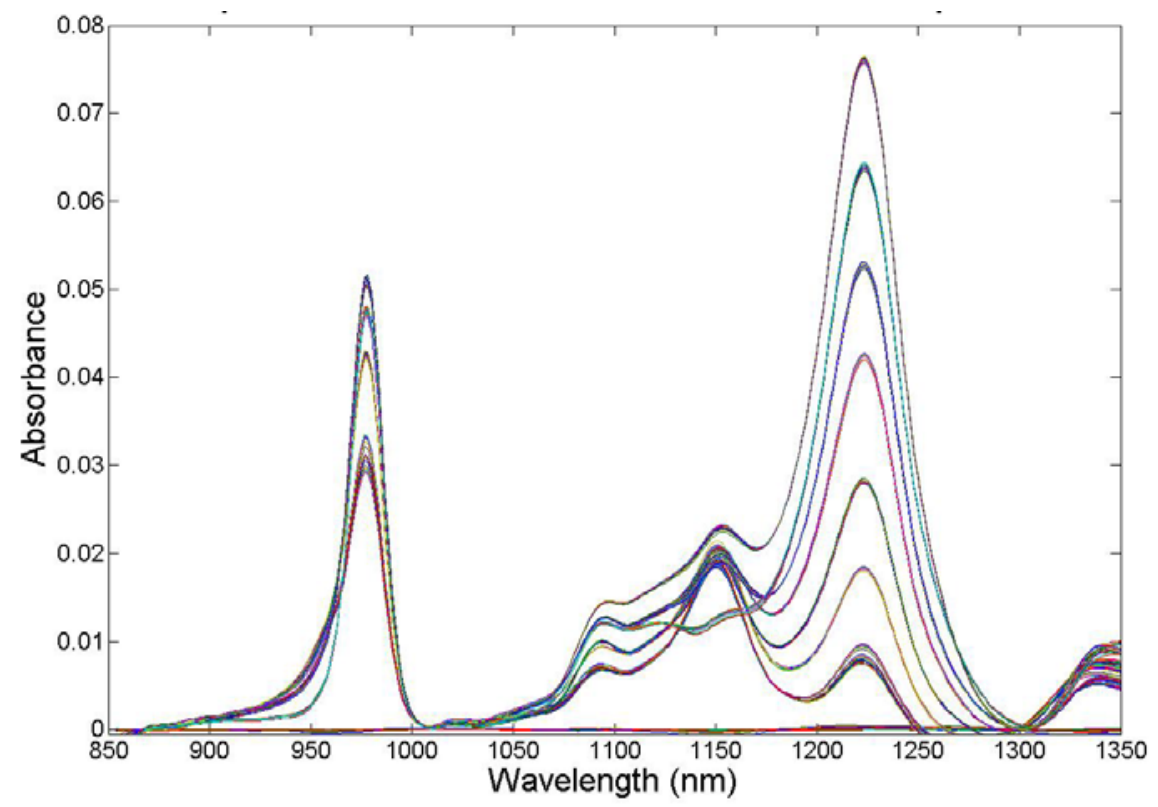

Figure 3.8. Variable Concentration Neptunium (V, VI) Standard Spectra Used as the Training Set for Chemometric Analysis.

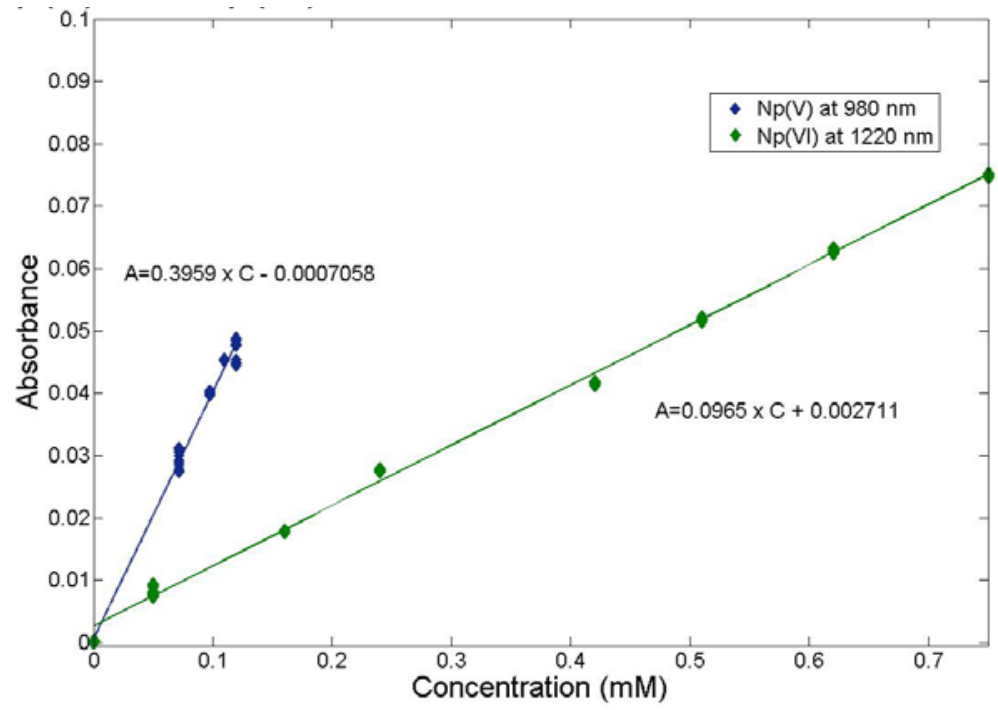

Figure 3.9. Linear Calibration Plots for Neptunium (V, VI) Data. 


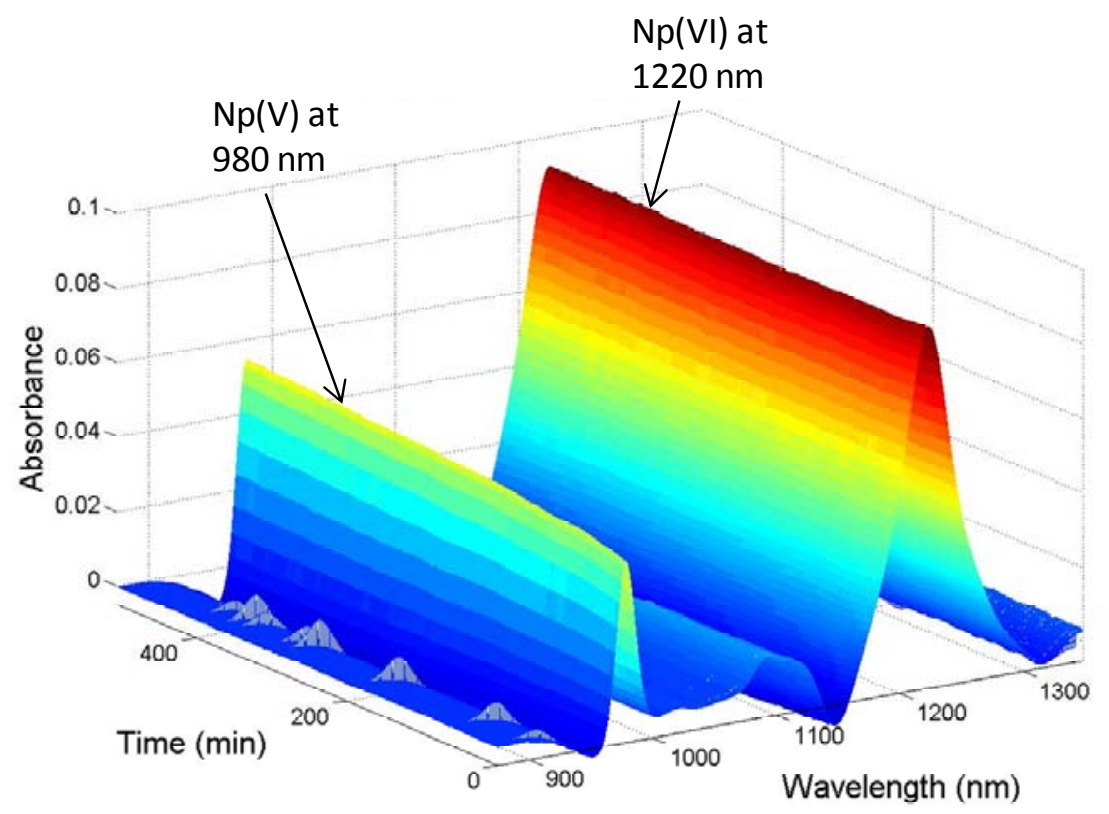

Figure 3.10. Long-Term Neptunium (V, VI) Spectral Measurements.

\subsection{Chapter 3 References}

Bryan, S.A., T.G. Levitskaia, and S.I. Sinkov. "Process Monitor Development Project: Acceptance Test Report”, PNNL-15360, Pacific Northwest National Laboratory, Richland, Washington 2005.

Bryan, SA, TG Levitskaia, and S Schlahta; "Raman Based Process Monitor for Continuous Real-Time Analysis of High Level Radioactive Waste Components" Waste Management 2008 Conference, February 24 -28, 2008, Phoenix, AZ. Conference Proceedings.

Bryan SA, and TG Levitskaia. "Monitoring and Control of UREX Radiochemical Processes." GLOBAL 2007, Boise, ID, September 10, 2007. Conference Proceedings.

Bürck J. 1991. "Spectrophotometric Determination of Uranium and Nitric Acid by Applying Partial Least Squares Regression to Uranium (VI) Absorption Spectra." Analytica Chimica Acta 254(1-2): 159-165.

Colston BJ and GR Choppin. 2001. "Evaluating the Performance of a Stopped-Flow Near-Infrared Spectrophotometer for Studying Fast Kinetics of Actinide Reactions." Journal of Radioanalytical and Nuclear Chemistry 251(1):21-26.

Long GL and JD Winefordner. 1983. "Limit of Detection. A Closer Look at the IUPAC Definition." Analytical Chemistry 55(7):712A-724A.

Steele H and RJ Taylor. 2007. "A Theoretical Study of the Inner-Sphere Disproportionation Reaction Mechanism of the Pentavalent Actinyl Ions." Inorganic Chemistry 46 (16):6311-6318. 



\title{
4.0 FY 2009 Progress: Electrochemically Modulated Separations
}

\author{
L.M. Arrigo, ${ }^{1}$ J. M. Schwantes, ${ }^{1}$ D. Duckworth,${ }^{1}$ M. Douglas, ${ }^{1}$ C. Fraga,${ }^{1}$ M. Liezers,,${ }^{1}$ S. Peper ${ }^{1}$
}

\subsection{Introduction}

Electrochemically modulated separation (EMS) is another technology that was demonstrated by PNNL. Originally developed as a trace elemental and isotopic separation and analysis technique for uranium and plutonium (Pretty, Duckworth, and Van Berkel 1998; Clark et al. 2006), it was tested here as an approach to facilitate rapid sampling of plutonium for destructive and nondestructive analyses.

EMS uses electrochemical redox adjustments of oxidation states to "trigger" reversible adsorption within a flow-through electrochemical cell. Separation of plutonium is achieved by a small voltage step applied to an anodized glassy carbon target electrode to turn "on" or "off" accumulation on the surface. When the proper potential is applied, plutonium (III) is converted to plutonium (IV), resulting in adsorption and accumulation on the target electrode. The plutonium on the electrode is rinsed clean of residual interfering actinides, activation, and fission products thus allowing direct gamma spectroscopic measurements to be made.

The EMS technique was used to separate plutonium from a diluted sample of the high burn up $(\sim 67 \mathrm{MWd} / \mathrm{kgU})$ BWR fuel with a 16-year decay time. The spent fuel solution, having approximately $\sim 3.6 \mu \mathrm{g}$ plutonium and $\sim 340 \mu \mathrm{g}$ uranium per injection, was passed through an anodized glassy carbon electrode along with other matrix elements. The electrochemical cell used in this experiment was a customized amperometric (flow-by) cell from Bioanalytical Systems (see Figure 4.1). A peristalitic pump was used to provide solution flow, and the samples were collected in $20-\mathrm{mL}$ scintillation vials for analysis by gamma spectroscopy and mass spectrometry.

Greater than 99 percent of each fission product was removed from the plutonium fraction during accumulation. In this experiment, no plutonium isotopes were seen after counting on HPGe detectors for 2.8 days indicating the amount of plutonium in the samples was below the detection limit. However, when the samples were analyzed by mass spectrometry, the strip solution was found to contain predominately plutonium, suggesting that the separation efficiency was high but the plutonium recovery was low.

Test results from the initial experiment are shown in Table 4.1. Test 1, using a simulated dissolver solution with a 29,000-fold dilution, had approximately 95-percent plutonium recovery and high cesium reduction. Test 2 used an actual dissolver solution with 160 -fold dilution. Surface area of this flow-by cell is limited to $1 \mathrm{~cm}^{2}$. In addition to plutonium, there is competition for the active surface area by other elements. Early tests indicate that zirconium competition is significant. This competition can result in greatly reduced plutonium accumulation. Comparing Test $2 \mathrm{a}$ and $2 \mathrm{~b}$, the uranium/plutonium ratio was improved, which is necessary to do accurate measurements by spectrometry; this suggests some degree of selectivity though further optimization is indicated.

\footnotetext{
${ }^{1}$ Pacific Northwest National Laboratory, Richland, Washington
} 

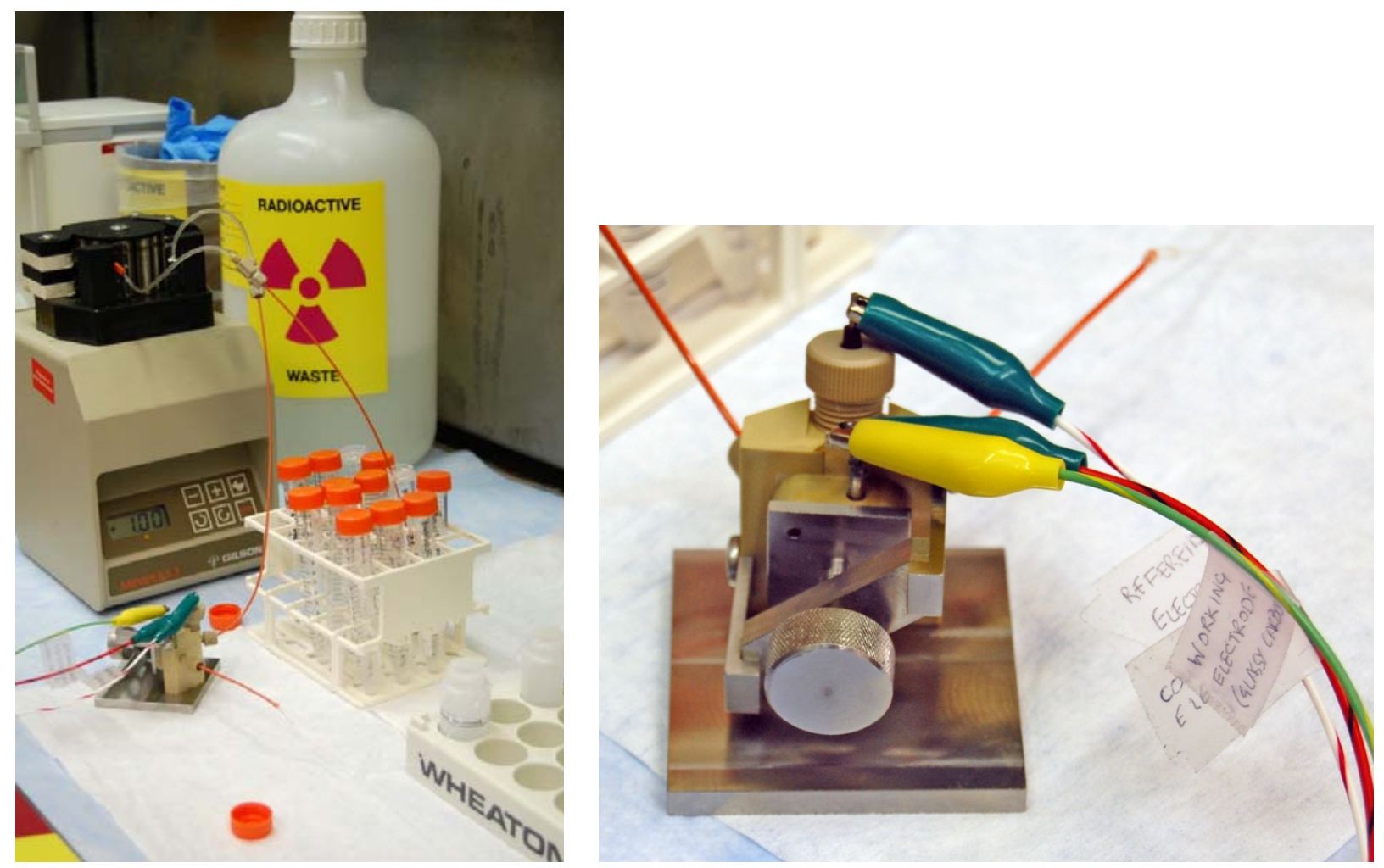

Figure 4.1. (left) Experimental Setup; (right) Small Volume Flow-by Electrochemical Cell for EMS, Showing the Three Electrode Cell.

Table 4.1. Results from the First Test of EMS Separation of Plutonium from BWR Fuel.

\begin{tabular}{lcccc}
\hline \multicolumn{1}{c}{ Test } & Dilution Factor & $\begin{array}{c}\text { Plutomium } \\
\text { Recovery }\end{array}$ & $\begin{array}{c}\text { Cesium Reduction } \\
\text { Factor }\end{array}$ & $\begin{array}{c}\text { Uranium/ } \\
\text { Plutonium }\end{array}$ \\
\hline 1. Simulated & 29,000 & $>95 \%$ & $99.99 \%$ & - \\
2a. Dissolver (No EMS) & 160 & - & - & 438 \\
2b. Dissolver (Post-EMS) & 160 & $5 \%$ & $99.8 \%$ & $36-150$ \\
\hline
\end{tabular}

Future work (being supported by the NA-22 Safeguards Portfolio) is focusing on the development of electrochemical cells that possess increased surface area and higher collection efficiency. A working electrode with increased surface will yield more active surface sites for plutonium accumulation and thus higher plutonium recoveries. Moreover, it will also allow for increased flow rates through the cell. Possible alternative working electrode materials being considered as a potential substitute to the current 1 $\mathrm{cm}^{2}$ flow-by glassy carbon cell are based on reticulated vitreous carbon; with a typical surface area of 100 $\mathrm{cm}^{2}$ for conventional disks and $1000 \mathrm{~cm}^{2}$ for the carbon fiber form. 


\subsection{Acknowledgments}

Initial advances in electrochemically-modulated separations were funded by DOE's National Nuclear Security Administration, Office of Research and Development (NA-22). Selective chemistry and cell design and testing were supported by the Laboratory Directed Research and Development Program at PNNL under the Sustainable Nuclear Power Initiative. PNNL is operated by Battelle for the under DOE contract number DE-AC06-76RLO-1830.

\subsection{Chapter 4 References}

Clark WJ, SH Park, DA Bostick, DC Duckworth, and GL Van Berkel. 2006. "Electrochemically Modulated Separation, Concentration, and Detection of Plutonium Using an Anodized Glassy Carbon Electrode and Inductively Coupled Plasma Mass Spectrometry." Analytical Chemistry 78(24): 8535-8542.

Pretty JR, DC Duckworth, and GJ Van Berkel. 1998. "Electrochemical Sample Pretreatment Coupled On-Line with ICP-MS: Analysis of Uranium Using an Anodically Conditioned Glassy Carbon Working Electrode." Analytical Chemistry 70(6):1141-1148. 



\section{Distribution}

No. of

Copies

\# Name

Organization

Address

City, State and ZIP Code

\# Organization

Address

City, State and ZIP Code

Name

Name

Name

Name

Name (\#)

\# Name

Organization

Address

City, State and ZIP Code
No. of

\section{Copies}

\# Foreign Distribution

\# Name

Organization

Address

Address line 2

COUNTRY

\# Local Distribution

Pacific Northwest National Laboratory

Name

Name

Mailstop

Name

Name

Name
Mailstop

Mailstop

Mailstop

(PDF) 




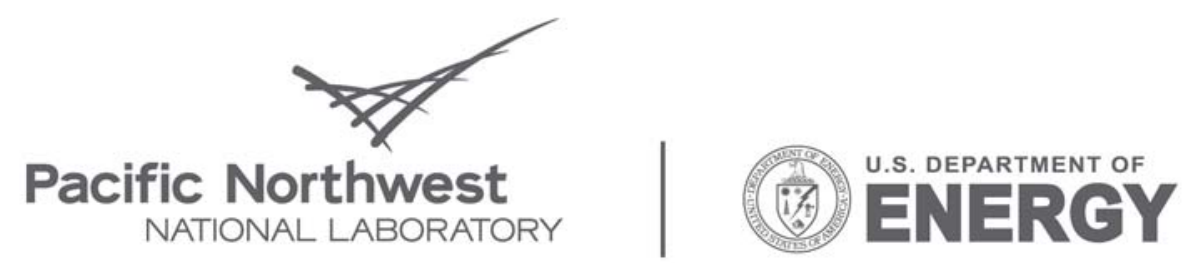

Proudly Operated by Battelle Since 1965

902 Battelle Boulevard

P.O. Box 999

Richland, WA 99352

1-888-375-PNNL (7665)

www.pnl.gov 